ANTONIO CARLOS FERNANDES DECCACHE

Dos efeitos da falência sobre a arbitragem

Tese de Doutorado

Orientador: Professor Doutor Haroldo Malheiros Duclerc Verçosa

UNIVERSIDADE DE SÃO PAULO

FACULDADE DE DIREITO

São Paulo 


\section{Dos efeitos da falência sobre a arbitragem}

Tese apresentada à Banca Examinadora de PósGraduação em Direito, da Faculdade de Direito da Universidade de São Paulo, como exigência parcial para a obtenção do título de Doutor em Direito, na área de concentração Direito Comercial (DCO), sob a orientação do Professor Doutor Haroldo Malheiros Duclerc Verçosa.

UNIVERSIDADE DE SÃO PAULO

FACULDADE DE DIREITO

São Paulo 
Deccache, Antonio Carlos Fernandes

Dos efeitos da falência sobre a arbitragem ;

Antonio Carlos Fernandes Deccache ; orientador

Haroldo Malheiros Duclerc Verçosa -- São Paulo, 2020.

$279 \mathrm{f}$.

Tese (Doutorado - Programa de Pós-Graduação em Direito Comercial) - Faculdade de Direito, Universidade de São Paulo, 2020.

1. Falência. 2. Arbitragem. 3. Convenção de arbitragem. 4. Procedimento arbitral. 5. Sentença arbitral. I. Verçosa, Haroldo Malheiros Duclerc, orient. II. Título. 


\section{TERMO DE APROVAÇÃO}

Nome: DECCACHE, Antonio Carlos Fernandes.

Título: Dos efeitos da falência sobre a arbitragem.

Tese apresentada à Banca Examinadora de PósGraduação em Direito, da Faculdade de Direito da Universidade de São Paulo, como exigência parcial para a obtenção do título de Doutor em Direito, na área de concentração Direito Comercial (DCO), sob a orientação do Professor Doutor Haroldo Malheiros Duclerc Verçosa.

Data de aprovação:

Banca examinadora

Prof. Dr. Instituição:

Julgamento: Assinatura:

Prof. Dr. Instituição:

Julgamento: Assinatura:

Prof. Dr. Instituição:

Julgamento: Assinatura:

Prof. Dr. Instituição:

Julgamento: Assinatura:

Prof. Dr. Instituição:

Julgamento: Assinatura: 



\section{RESUMO}

DECCACHE, Antonio Carlos Fernandes. Dos efeitos da falência sobre a arbitragem. 2020. 279 f. Tese (Doutorado em Direito Comercial) - Faculdade de Direito da Universidade de São Paulo. São Paulo, 2020.

Esta tese analisa os efeitos da falência sobre a arbitragem. A falência constitui um regime complexo, formado por regras materiais e processuais, criado para lidar com o problema da insolvência empresarial. Tem natureza de execução coletiva, reunindo todos os credores do falido e todos os seus bens, que devem ser liquidados a fim de pagar os credores. Para a consecução dos seus objetivos, a decretação da falência opera efeitos diretos sobre a pessoa do devedor, seus bens, seus contratos e seus processos. O processo falimentar realiza-se mediante procedimento administrado pelo Poder Judiciário, centralizado, público, com a finalidade de lidar com os diversos interesses envolvidos. Diversamente, a arbitragem é meio privado de solução de controvérsias pelo qual partes capazes elegem um terceiro, da sua confiança, para resolver litígio versando sobre direitos patrimoniais disponíveis. Tem natureza jurisdicional e caracteriza-se por constituir alternativa privada, rápida, flexível e especializada de dirimir demandas que admitem transação. Seu procedimento tem natureza de processo de conhecimento, terminando com a prolação de sentença, e constitui processo descentralizado, privado, usualmente sigiloso, no qual as partes têm ampla liberdade para definir as regras materiais e processuais aplicáveis. Enquanto a falência constitui sistema que visa lidar com interesses de ordem pública - sendo, portanto, controlado pelo Estado, centralizado, público e coletivo - a arbitragem pauta-se na autonomia da vontade, na descentralização do sistema de resolução de litígios, lida com interesses privados e é usualmente sigilosa. Considerando as relevantes diferenças entre os dois institutos, questiona-se em que condições a falência e a arbitragem podem coexistir. O que se propõe neste trabalho é, portanto, analisar quais são os efeitos que a falência opera sobre a arbitragem e como esses efeitos impactam na convivência entre os dois institutos. Para tanto, este estudo organiza-se em duas partes: parte I, na qual são apresentadas noções introdutórias da falência e da arbitragem, que servem para assentar as premissas utilizadas na análise; e parte II, na qual são analisados os efeitos propriamente ditos da falência sobre a arbitragem. A parte I está dividida em dois capítulos, nos quais se trata, sucessivamente, da falência e da arbitragem. Já a parte II está dividida em três capítulos, nos quais se trata, sucessivamente: (i) dos efeitos da falência sobre a convenção de arbitragem; (ii) dos efeitos da falência sobre o procedimento arbitral; e (iii) dos efeitos da falência sobre a sentença arbitral. Ao final, conclui-se que, apesar de a falência operar efeitos sobre alguns aspectos da arbitragem, impondo-lhe limites no contexto falimentar, isso não as torna incompatíveis. Aduz-se que a falência não invalida a convenção arbitral celebrada antes da falência, nem impede sua celebração pelo administrador, que, entretanto, depende de autorização judicial. Comprovase, também, que o advento da falência não atrai nem suspende os procedimentos arbitrais, mas impõe condições para que o processo possa se desenvolver. Por fim, evidencia-se que a sentença arbitral, uma vez proferida, deve ser submetida a verificação no processo falimentar.

Palavras-chave: Falência. Arbitragem. Convenção de arbitragem. Procedimento arbitral. Sentença arbitral. 



\begin{abstract}
DECCACHE, Antonio Carlos Fernandes. The effects of bankruptcy on arbitration. 2020. 279 pp. Thesis (Doctorate in Commercial Law) - Law School of Universidade de São Paulo. São Paulo, 2020.

This thesis analyses the effects of bankruptcy on arbitration. Bankruptcy is a complex regime, consisting of material and procedural rules, created to deal with the problem of corporate insolvency. Its nature is one of collective execution, congregating all the creditors of the bankrupt company and all its assets, which are to be liquidated in order to repay the creditors. To achieve its objectives, the decree of bankruptcy has a direct effect on the person of the debtor, its assets, its contacts and its processes. The bankruptcy process is administered by the courts, is centralized, public, and aimed at dealing with the various interests involved. On the other hand, arbitration is a private means of dispute resolution by which capable parties elect a third party, in whom they have confidence, to resolve litigation relating to available property rights. It is judicial in nature and its task is to provide a private, quick, flexible and specialized alternative to settle disputes that are subject to transaction. It has cognitive nature, ends with the rendering of an award, and the process is decentralized, private and usually confidential, with the parties being largely free to define the material and the procedural rules that will apply. While bankruptcy is a system intended to deal with interests of public order - and is therefore controlled by the State, centralized, public and collective - , arbitration is based on party autonomy and decentralization of the dispute resolution system, concerns private interests and is usually confidential. Taking into account the major differences between the two institutions, one may question under what conditions bankruptcy and arbitration could coexist. What I propose in this essay, then, is to identify the effects that bankruptcy has on arbitration, and how these effects impact the way the two institutions coexist. For this I have divided the study into two parts: part I, where I present introductory notions of bankruptcy and arbitration, which will serve to establish the premises used in the analysis; and part II, in which I analyze the actual effects of bankruptcy on arbitration. Part I is divided into two chapters, one each for bankruptcy and arbitration. Part II, in turn, is divided into three chapters, as follows: (i) the effects of bankruptcy on the arbitration agreement; (ii) the effects of bankruptcy on the arbitration proceeding; and (iii) the effects of bankruptcy on the arbitration award. At the end, I reach the conclusion that, although bankruptcy affects certain aspects of arbitration, imposing limits on it in the context of the bankruptcy, this does not make them incompatible. I argue that bankruptcy does not invalidate an arbitration agreement signed before the bankruptcy, or prevent a trustee from executing such an agreement, which, however, requires court approval. I also demonstrate that bankruptcy does not attract or suspend arbitration proceedings, but imposes conditions on the way the proceedings work. Lastly, I show that the arbitration award, once issued, must be submitted to verification in the bankruptcy process.
\end{abstract}

Keywords: Bankruptcy. Arbitration. Arbitration Agreement. Arbitration Proceeding. Arbitration Award. 



\section{RIASSUNTO}

DECCACHE, Antonio Carlos Fernandes. Degli effetti del fallimento sull'arbitrato 2020. 279 f. Tesi (Dottorato in Diritto Commerciale) - Faculdade de Direito da Universidade de São Paulo (Facoltà di Giurisprudenza dell’Università di San Paolo). São Paulo, 2020.

La presente tesi analizza gli effetti del fallimento sull'arbitrato. Il fallimento costituisce un regime complesso formato da regole materiali e processuali, creato per trattare il problema dell'insolvenza aziendale. Ha la natura di esecuzione collettiva, riunendo tutti i creditori del fallito e tutti i suoi beni, che devono essere liquidati al fine di pagare i creditori. Per il compimento dei suoi obiettivi, la dichiarazione di fallimento opera effetti diretti sulla persona del debitore, sui suoi beni, sui suoi contratti e sui suoi processi. La procedura fallimentare si svolge tramite una procedura amministrata dal Potere Giudiziario centralizzata, pubblica, con la finalità di trattare i diversi interessi delle parti coinvolte. Diversamente, l'arbitrato è un mezzo privato di soluzione di controversie per il quale le parti capaci scelgono un terzo della loro fiducia per risolvere una lite che ha come oggetto dei diritti patrimoniali disponibili. Di natura giurisdizionale, è caratterizzato dall'essere un'alternativa privata, veloce, flessibile e specializzata per risolvere questioni che ammettono transazioni. Il suo procedimento ha la natura di un processo di cognizione, finendo con la pronuncia di una sentenza, e costituisce un processo decentralizzato, privato, usualmente confidenziale, nel quale le parti hanno un'ampia libertà per definire le regole materiali e processuali applicabili. Mentre il fallimento costituisce un sistema che ha come obbiettivo gestire gli interessi di ordine pubblico - essendo, quindi, controllato dallo Stato, centralizzato, pubblico e collettivo —, l'arbitrato si fonda sull'autonomia della volontà, sulla decentralizzazione del sistema di risoluzione delle liti, gestisce degli interessi privati ed è usualmente confidenziale. Considerando le rilevanti differenze tra $\mathrm{i}$ due istituti, ci si domanda in quali condizioni il fallimento e l'arbitrato possano coesistere. Quello che si propone in questo studio è dunque di analizzare quali siano gli effetti che il fallimento opera sull'arbitrato e gli impatti di tali effetti sulla convivenza tra i due istituti. Per farlo, il presente studio si organizza in due parti: parte I, nella quale sono presentate delle nozioni introduttive sul fallimento e sull'arbitrato che servono per stabilire le premesse utilizzate nell'analisi; e parte II, nella quale si analizzano gli effetti veri e propri del fallimento sull'arbitrato. La parte I è divisa in due capitoli, nei quali si tratta, successivamente, del fallimento e dell'arbitrato. Già la parte II è divisa in tre capitoli, nei quali si tratta, successivamente: (i) degli effetti del fallimento sulla convenzione di arbitrato; (ii) degli effetti del fallimento sulla procedura arbitrale; e (iii) degli effetti del fallimento sulla sentenza arbitrale. Alla fine, si conclude che, nonostante il fallimento abbia degli effetti su alcuni aspetti dell'arbitrato, imponendogli dei limiti nel contesto fallimentare, questo non li rende incompatibili. Si adduce che il fallimento non invalida la convenzione arbitrale conclusa prima del fallimento né impedisce la sua conclusione da parte dell'curatore, il che, tuttavia, dipende dall'autorizzazione giudiziale. Si attesta anche che l'avvento del fallimento non attrae né sospende i procedimenti arbitrali, ma impone condizioni per lo svolgimento del processo. Infine, si evidenzia che la sentenza arbitrale, una volta emessa, deve essere sottoposta a verificazione nel processo fallimentare.

Parole chiave: Fallimento. Arbitrato. Convenzione di arbitrato. Procedimento arbitrale. Sentenza arbitrale. 



\section{LISTA DE ABREVIATURAS}

CC

CCEE

CCI

$\mathrm{CF}$

$\mathrm{CPC}$

CVM

EIRELI

LARB

LREF

LSA

STJ

TJDF

TJSP

UNCITRAL

CTN
Código Civil (Lei n. 10.406, de 10 de janeiro de 2002)

Câmara de Comercialização de Energia Elétrica

Câmara de Comércio Internacional

Constituição Federal

Código de Processo Civil (Lei n. 13.105, de 16 de março de 2015)

Comissão de Valores Mobiliários

Empresa Individual de Responsabilidade Limitada

Lei de Arbitragem (Lei n. 9.307, de 23 de setembro de 1996)

Lei de Recuperação de Empresas e Falência (Lei n. 11.101, de 9 de fevereiro de 2005)

Lei das Sociedades por Ação (Lei n. 6.404, de 15 de dezembro de 1976)

Superior Tribunal de Justiça

Tribunal de Justiça do Distrito Federal

Tribunal de Justiça de São Paulo

United Nations Commission on International Trade Law

Código Tributário Nacional (Lei n. 5.172, de 25 de outubro de 1966) 



\section{SUMÁRIO}

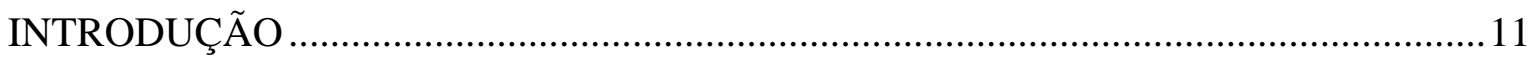

PARTE I - NOÇÕES INTRODUTÓRIAS DOS INSTITUTOS DA FALÊNCIA E DA

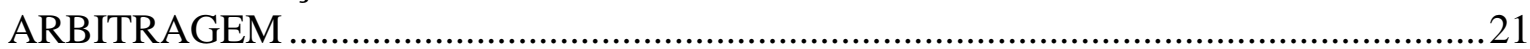

1 NOÇÕES INTRODUTÓRIAS DA FALÊNCIA RELEVANTES PARA A TESE

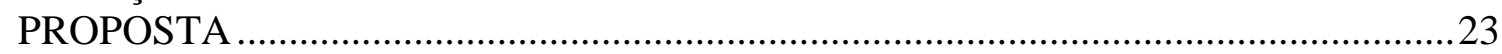

1 Conceito, objetivos, alguns personagens e a natureza jurídica da falência ...............23

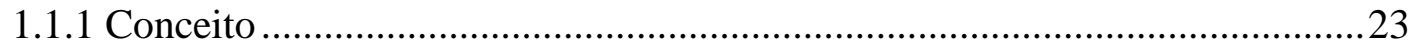

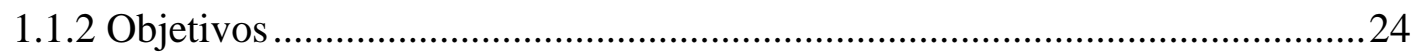

1.1.3 Alguns personagens: o falido, a massa falida, o administrador judicial e o

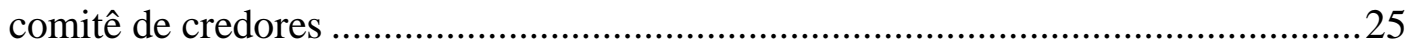

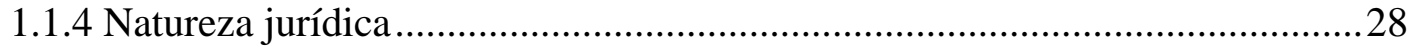

1.2 Princípios norteadores relevantes para a tese proposta..............................................30

1.2.1 Paridade entre os credores (par conditio creditorium) ..........................................31

1.2.2 Unidade e universalidade do juízo falimentar ....................................................32

1.2.3 Celeridade e economia processual ....................................................................34

1.2.4 Viabilidade e maximização do valor dos ativos do falido ..................................34

1.2.5 Publicidade do processo..................................................................................

1.3 Os efeitos da falência sobre a pessoa, os bens, os contratos e os processos do falido

1.3.1 Dos efeitos da falência sobre a pessoa e os bens do falido...............................37

1.3.2 Dos efeitos da falência sobre os contratos do falido........................................46

1.3.3 Dos efeitos da falência sobre os processos do falido......................................4 47

1.3.3.1 Vis attractiva, universalidade e indivisibilidade do juízo falimentar ......47

1.3.3.2 Suspensão das ações e execuções e dos correspondentes prazos

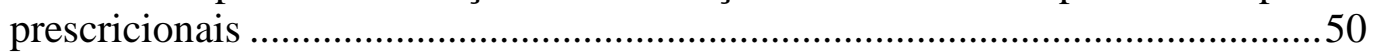

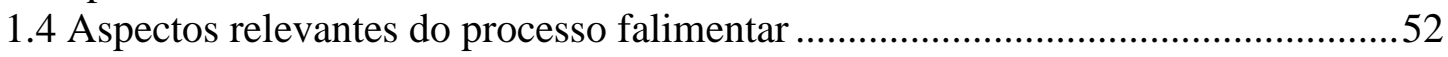

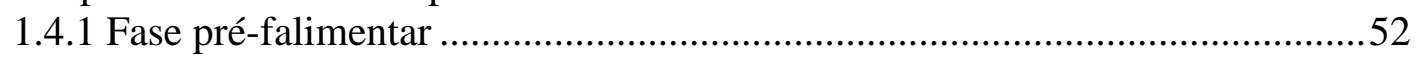

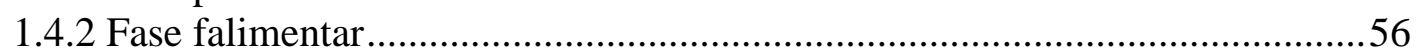

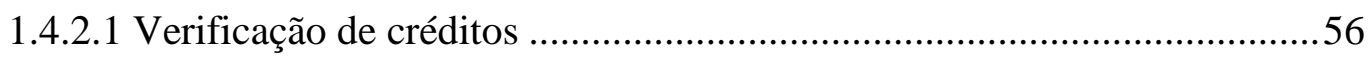

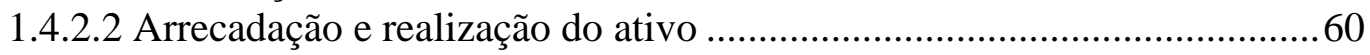

1.5 Aspectos relevantes do encerramento da falência ................................................63

2 NOÇÕES INTRODUTÓRIAS DA ARBITRAGEM RELEVANTES PARA A TESE

PROPOSTA …………………………………………………………....65

2.1 Conceito e natureza jurídica da arbitragem ............................................................65

2.2 Princípios norteadores relevantes para a tese proposta............................................ 70

2.2.1 Do princípio da autonomia da vontade ……………………………………....

2.2.2 Do princípio da autonomia da convenção de arbitragem ..................................71

2.2.3 Do princípio Kompetenz-Kompetenz ……………………..............................72

2.2.4 Do princípio do devido processo legal ............................................................75

2.3 A convenção de arbitragem .........................................................................78

2.3.1 Conceito e modalidades ...............................................................................79

2.3.2 A natureza jurídica da convenção de arbitragem.............................................. 81

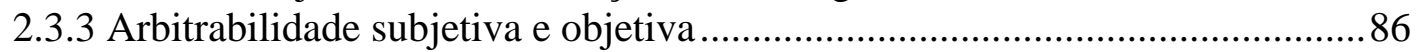

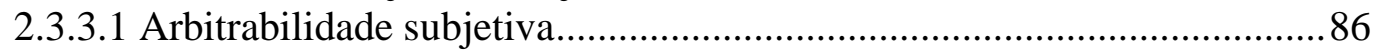

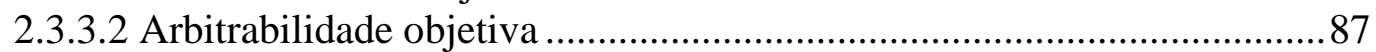

2.3.4 Dos efeitos da convenção de arbitragem ......................................................... 89

2.4 Aspectos relevantes do procedimento arbitral ................................................... 
2.4.2 Das custas, das despesas e dos honorários de sucumbência no procedimento

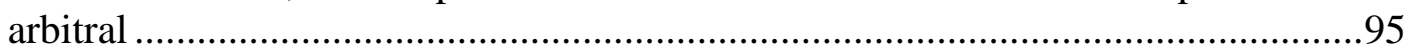

2.5 Aspectos relevantes da sentença arbitral....................................................... 100

PARTE II - DOS EFEITOS DA FALÊNCIA SOBRE A ARBITRAGEM .....................105

3 DOS EFEITOS DA FALÊNCIA SOBRE A CONVENÇÃO DE ARBITRAGEM ..107

3.1. Dos efeitos da falência sobre a pessoa e os bens do falido e seu impacto na convenção de arbitragem

3.1.1. A convenção de arbitragem firmada pelo falido antes do decreto de quebra é

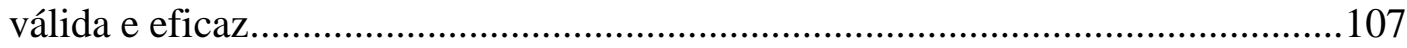

3.1.1.1 O decreto de falência não torna o falido incapaz ...................................112

3.1.1.1.1 O equívoco da jurisprudência ........................................................119

3.1.1.2 $\mathrm{O}$ decreto de falência não torna os bens do falido indisponíveis ...........124

3.1.1.2.1 O acerto da jurisprudência ............................................................126

3.1.2 A convenção de arbitragem firmada pelo falido depois do decreto de quebra é

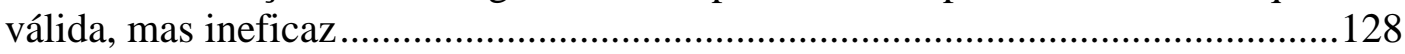

3.1.2.1 A convenção de arbitragem firmada pelo falido após o decreto de quebra é

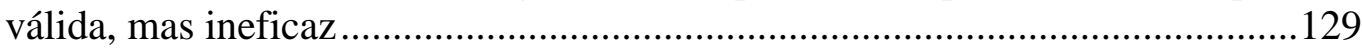

3.1.2.2 A ineficácia da convenção de arbitragem firmada pelo falido após o decreto de quebra é relativa, não absoluta

3.1.3 A convenção de arbitragem firmada pelo administrador judicial depois do decreto de quebra é válida, mas depende de autorização judicial.........................135

3.1.3.1 A convenção de arbitragem firmada pelo administrador judicial depois do

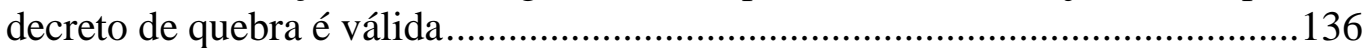

3.1.3.2 O administrador deve obter autorização judicial para firmar a convenção de arbitragem.

3.2 Dos efeitos da falência sobre os contratos do falido e seu impacto na convenção de arbitragem

3.2.1 A submissão da convenção de arbitragem à regra do art. 117 da LREF deve ser analisada de forma autônoma e independente ....................................................144 3.2.2 A convenção de arbitragem não se submete à regra do art. 117 da LREF porque não tem natureza de contrato bilateral 147 3.2.3 A convenção de arbitragem não se submete à regra do art. 117 da LREF porque

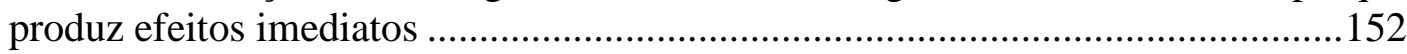

4 DOS EFEITOS DA FALÊNCIA SOBRE O PROCEDIMENTO ARBITRAL ..........157

4.1 Dos efeitos da vis attractiva do juízo falimentar sobre o procedimento arbitral .157

4.1.1 As arbitragens não são atraídas para o juízo falimentar porque têm natureza cognitiva..... 158

4.1.1.1 Duas exceções relevantes 166 4.1.2 O administrador judicial, agindo em nome próprio, deve substituir o falido nos procedimentos arbitrais, sob pena de nulidade 174

4.1.2.1 Não há sub-rogação na convenção de arbitragem 178

4.1.3 O falido tem legitimidade para intervir como assistente nos procedimentos arbitrais 180

4.2.1 As arbitragens não são suspensas com o decreto de quebra do falido porque têm natureza cognitiva

4.2.2 $\mathrm{O}$ árbitro tem competência para decidir sobre pedido de reserva do art. $6^{\circ}, \S 3^{\circ}$, da LREF, mas sua decisão pode ser recusada pelo juízo falimentar em casos excepcionais 
4.3 Dos efeitos da falência sobre a confidencialidade do procedimento arbitral

4.3.1 As arbitragens envolvendo os bens e direitos do falido mantêm-se privadas, mas o falido e o administrador judicial têm o dever de prestar, na falência, as informações necessárias para o desenvolvimento do processo falimentar 197

4.3.2 A sentença arbitral se tornará pública no contexto do processo falimentar..205

4.4 Dos efeitos da falência sobre as custas, as despesas e os honorários de sucumbência do procedimento arbitral

4.4.1 $\mathrm{O}$ administrador judicial está obrigado a pagar as custas arbitrais, mas a falta de recursos para fazê-lo pode tornar a convenção de arbitragem inexequível ......207

4.4.1.1 Necessária mitigação do efeito negativo da convenção de arbitragem..211

4.4.1.2 Necessária mitigação do efeito negativo do princípio Kompetenz-

Kompetenz.....

4.4.2 Afora casos excepcionais, o administrador judicial deve pedir autorização do juízo falimentar para realizar o pagamento das custas arbitrais 221

4.4.3 O tratamento das custas, despesas e honorários de sucumbência arbitrais na falência

5 DOS EFEITOS DA FALÊNCIA SOBRE A SENTENÇA ARBITRAL 227

5.1 Os créditos representados por sentença arbitral devem submeter-se ao processo de verificação de créditos na falência

$5.2 \mathrm{O}$ conteúdo da impugnação no caso de crédito representado por sentença arbitral fica restrito às matérias constantes dos arts. $525, \S 1^{\circ}$, do CPC, e 32 da LARB 230

CONSIDERAÇÕES FINAIS 237

REFERÊNCIAS. 



\section{INTRODUÇÃO}

Esta tese analisa os efeitos da falência sobre a arbitragem.

A falência constitui um regime complexo, formado por regras materiais e processuais, criado para lidar com o problema da insolvência empresarial. Por meio da falência, procede-se à liquidação organizada dos ativos do devedor para o pagamento dos seus credores de acordo com a ordem legal. Os objetivos do instituto são o pagamento dos credores, respeitada a máxima da par conditio creditorium, e o saneamento do mercado, com a exclusão das empresas inviáveis e alocação mais eficiente dos recursos em outros lugares, buscando-se contribuir para a melhora do crédito em geral. Congrega a falência, pois, além de interesses privados, interesses de ordem pública. A falência tem natureza de execução coletiva, assim reunindo todos os credores do falido e todos os seus bens e direitos, os quais devem ser liquidados e seu produto repartido nos termos da lei. Para dar consecução aos seus objetivos, a decretação da falência opera efeitos diretos sobre a pessoa do devedor, seus bens,

seus contratos e seus processos. É o caso, por exemplo, da inabilitação para o exercício da atividade empresarial; da perda, pelo falido, do poder de administração e de disposição dos bens submetidos ao concurso; da prerrogativa garantida ao administrador judicial de resolver os contratos bilaterais firmados, mas ainda não executados, pelo falido; da regra que determina a atração das ações envolvendo os bens e direitos do falido para o juízo falimentar; da regra que estabelece a suspensão de todas as ações e execuções contra o devedor; e também da regra que torna obrigatória a submissão de todos os créditos contra o falido à processo de verificação perante o juízo falimentar. A falência se realiza por meio de procedimento administrado pelo Poder Judiciário, centralizado, público, com a finalidade de lidar com os diversos interesses envolvidos. Encerra-se com a prolação de sentença, o que não implica per se na extinção das obrigações falido, nem da sua personalidade jurídica, que sobrevivem ao processo falimentar.

Saindo do regime falimentar e entrando no arbitral, pode-se afirmar que a arbitragem é meio privado de solução de controvérsias, por meio do qual partes capazes elegem um terceiro, da sua confiança, para resolver litígio versando sobre direitos patrimoniais disponíveis. Tem natureza jurisdicional e caracteriza-se por constituir alternativa privada, rápida, flexível e especializada de dirimir demandas que em geral admitem transação. A arbitragem apoia-se sempre na vontade das partes. Só aqueles que escolheram decidir seus conflitos pela via arbitral têm o dever de se submeter a ela. A arbitragem se contrata por 
meio do negócio jurídico do tipo "convenção arbitral". Para que seja tida como válida e produza efeitos, a convenção de arbitragem deve respeitar requisitos fixados em lei. Deve necessariamente ser firmada por partes capazes e só pode versar sobre direitos patrimoniais disponíveis. Uma vez contratada, a arbitragem é vinculativa para as partes, produz efeitos desde a contratação e afasta a jurisdição do Poder Judiciário para dirimir o mérito da controvérsia. O procedimento arbitral tem natureza de processo de conhecimento, terminando com a prolação de sentença. Trata-se de procedimento descentralizado, privado, usualmente sigiloso, no qual as partes têm ampla liberdade para definir as regras materiais e processuais aplicáveis. A arbitragem se encerra com a prolação da sentença arbitral, que não se sujeita a recurso e tem força de título judicial.

Dessa breve descrição dos institutos da falência e da arbitragem, depreende-se que, enquanto a falência constitui sistema que visa lidar com interesses de ordem pública, sendo, por isso, controlado pelo Estado, de natureza centralizada, pública e coletiva; por seu turno, a arbitragem pauta-se na autonomia da vontade, na descentralização do sistema de resolução de litígios, lida com interesses privados, e é usualmente sigilosa. Aparentemente, portanto, a relação entre a falência e a arbitragem

[...] apresenta um conflito de extremos quase polares: a política da falência exerce uma atração inexorável em direção à centralização, enquanto a política de arbitragem defende uma abordagem descentralizada em direção à resolução de controvérsias. ${ }^{1}$ (ESTADOS UNIDOS DA AMÉRICA. In re United States Lines, 197 F.3d 631 (2d Cir.) 1999)

O aparente conflito faz surgir uma série de indagações. Imagine-se, por exemplo, a hipótese de empresa que, após firmar convenção de arbitragem, cai em insolvência e tem a sua falência decretada. Nesse caso, cabe questionar se o advento da quebra afeta a capacidade do falido e/ou a disponibilidade sobre seus bens, invalidando a convenção de arbitragem. Ademais, ainda se pergunta: seria o caso de aplicar a regra que permite ao administrador denunciar os contratos bilaterais, autorizando-o a resolver o pacto arbitral? Considere-se, agora, situação diversa, na qual o falido, ignorando a decretação da falência, venha a firmar convenção de arbitragem versando sobre os bens e direitos submetidos ao concurso. Seria, nesse cenário, a cláusula arbitral inválida? E o administrador judicial? Poderia ele, no exercício das suas atividades no curso da falência, firmar cláusula arbitral?

\footnotetext{
${ }^{1}$ Tradução livre de: “[...] presents a conflict of near polar extremes: bankruptcy policy exerts an inexorable pull towards centralization while arbitration policy advocates a decentralized approach towards dispute resolution."
} 
Haveria necessidade de obter autorização judicial? Ademais, avente-se a ocorrência de, no curso de um procedimento de arbitragem, vir uma das partes a ter sua falência decretada. Nesse caso, o processo arbitral deve ser atraído para o juízo falimentar ou suspenso por força da quebra? Em caso negativo, como se dividem as competências entre o tribunal arbitral e o juízo falimentar? Qual seria o papel do administrador na arbitragem? Deve o Ministério Público participar do processo arbitral? Deve o sigilo do procedimento ceder considerando a natureza pública e coletiva da falência? E como funciona o pagamento das custas e despesas da arbitragem se o falido não tiver recursos para suportá-los? Por fim, mencionese ainda a circunstância de, antes ou depois da decretação da falência, vir ser proferida uma sentença arbitral envolvendo os bens e direitos do falido. Nesse caso, deve a sentença ser apresentada no processo falimentar? Como funciona o processo de habilitação e classificação do respectivo crédito no quadro geral de credores?

Enfim, são todas hipóteses corriqueiras, que levantam perguntas relevantes para entender a relação entre a falência e a arbitragem, que ainda aguardam respostas satisfatórias.

No contexto internacional, a tensão aqui apresentada já foi objeto de vários estudos doutrinários, havendo, ademais, farta jurisprudência estatal versando sobre o tema. ${ }^{2}$ Como

2 ANCEL, Pascal, Arbitrage et procedures collectives, Revue de l'Arbitrage, v. 1983, at 255 et seq.; BACCAGLINI, Laura. L'opponibilità al curatore degli accordi arbitrali conclusi dal fallito, in Fallimento e arbitrato rituale profili di interrelazione e autonomia tra i due procedimenti, Università degli Studi di Trento, p. 15, 2018; BADEL, Francoise. Faillite et Arbitrage International. ASA Bulletin, Kluwer Law International 2007, v. 25. i. 1, p. 36/47; BERSET, Dominique; e LÉVY, Laurent. Faillite et arbitrage. In: ASA Bulletin, Kluwer Law International, v. 16, i. 4), 1998. p. 664/680; BOVE, Mauro. Arbitrato e Fallimento, 2012. Disponível em: <http://www.judicium.it/arbitrato-e-fallimento/>. Acesso em: 08/dez./2019; CANALE, Guido. Clausola Arbitrale in Crisi di impresa e procedure concorsuali diretto da Oreste Cagnasso e Luciano Panzani, V. I, UTET, p. 1568, 2016; CASTAGNOLA, Angelo. Procedimento arbitral, lodo e fallimento. In: Rivista Trimestrale di Diritto e Procedura Civile, fasc.3, 2016, p. 821; FOUCHARD, Philippe. Arbitrage et faillite. Revue de l'Arbitrage, v. 1998, i.3, p. 471/494, 1998; GASIOROWSKI, Kuba; KOS, Rafal. Elektrim case comes to na end, 23/07/2015. Disponível el $<$ https://www.internationallawoffice.com/Newsletters/Arbitration-ADR/Poland/Kubas-Kos-

Gakowski/Elektrim-case-era-comes-to-an-end?redir=1>. Acesso em: 25/nov./2019; KIRGIS, Paul. Arbitration, Bankruptcy and Public Policy: a contractarian analysis. American Bankruptcy Institute Law Review, v. 17, n. 2, 2009; LEITÃO, Luís Manuel Teles de Menezes. Os efeitos da insolvência sobre os processos de arbitragem internacional. In: Revista de Arbitragem e Mediação, v. 43/2014, out.-dez./2014, p. 297-305; LIEBSCHER, Christoph. 'Part II Substantive Rules on Arbitrability, Chapter 9 - Insolvency and Arbitrability. In: MISTELIS, Loukas A.; BREKOULAKIS, Stravos (eds), Arbitrability: International and Comparative Perspectives, International Arbitration Law Library, Volume 19. Kluwer Law International; Kluwer Law International, 2009, p. 165-178; MANTILLA-SERRANO, Fernando. International arbitration and insolvency proceedings. Arbitration International, Londres, v. 11, n. 1, p. 51-74, 1995; NAEGELI, Georg. Chapter III: The Award and the Courts - Bankruptcy and Arbitration - What Should Prevail? The Impact of Bankruptcy on Pending Arbitral Proceedings. In: Austrian Yearbook on International Arbitration 2010, Austrian Yearbook on International Arbitration, Volume 2010, p. 193/207; NITROLA, Marina. Arbitrato e Fallimento, in I contratti 8-9/2012, p. 759, 2012; RESNICK, Alan. The Enforceability of Arbitration Clauses in Bankruptcy. American Bankruptcy Institute Law Review, v. 15, 2007, p. 183-221; ROSELL, José; e PRAGER, Harvey. International Arbitration and Bankruptcy: United States, France and the ICC. In: Journal of International Arbitration, Kluwer Law International 2001, Volume 18, Issue 4, p. 417 - 434; VORBURGER, 
se verá neste trabalho, entretanto, as soluções adotadas nos diversos países variam com grande frequência, mostrando que a questão está longe de estar pacificada no cenário internacional. A situação não é muito diferente no Brasil. Apesar de haver alguns estudos e julgados sobre o assunto, ${ }^{3}$ aqueles que se propuseram a tratar do tema o fizeram exclusivamente a partir da lógica do instituto da arbitragem, sem aprofundar nos fundamentos do direito comercial, notadamente do direito falimentar, chegando a conclusões que sempre prestigiam a manutenção da arbitragem em detrimento da falência. Além disso, não há, até o momento, uma única tese no direito brasileiro que se proponha a analisar a

Simon. International Arbitration and Cross-Border Insolvency: Comparative perspectives. Kluwer International, 2014; VOSER, Nathalie; GEORGE, Anya. Insolvency and arbitration: Swiss Supreme Court revisits its Vivendi vs. Elektrim decision. Kluwer Arbitration Blog, 05/12/2012. Disponível em: $<$ http://arbitrationblog.kluwerarbitration.com/2012/12/05/insolvency-and-arbitration-swiss-supreme-courtrevisits-its-vivendi-vs-elektrim-decision/>. Acesso em: 22/nov./2009; WAGNER, Philipp. Insolvency and Arbitration: A Pelading for Internatonal Insolvency Law, 5 Disp. Rsol. Int'1 189 (2011); ZUCCONI GALLI FONSECA, Elena. Ancora su arbitrato rituale e fallimento, in Rivista Dell'arbitrato fasc.1, p. 1, 2014.

${ }^{3}$ ALVES, Rafael Francisco; e VERONESE, Ligia Espolaor. Arbitragem e empresas em crise: o acesso à Justiça e o cumprimento da convenção de arbitragem em vista da incapacidade financeira de uma das partes. In: Revista do Advogado, ano XXXVI, n. 131, out/2016, p. 176/187; ARMELIN, Donaldo. A arbitragem, a falência e a liquidação extrajudicial. In: Revista de Arbitragem e Mediação, ano 4, n. 13, abr.-jun./2007; BALBINO, Inês. A arbitrabilidade do Direito Falimentar. In: LEMES, Selma M. Ferreira; e BALBINO, Inês (coord.). Arbitragem. Temas Contemporâneos. São Paulo: Quartier Latin, 2012, p. 199/219; BENETI, Giovana. Arbitragem e empresas em crise. O problema da arbitrabilidade objetiva. In: Revista Jurídica LusoBrasileira, ano 5 (2019), n. 1, p. 879-917; CORREA, Raphael Nehin. Arbitragem e Insolvência. In: Arbitragem no Brasil (vários autores). São Paulo: Impressão Régia, 2010; FARIA, Luis Cláudio Furtado; COZER, Felipe Rodrigues. A arbitragem e a recuperação judicial em um estudo sobre a conveniência e possíveis conflitos entre os institutos. Revista de Arbitragem e Mediação, São Paulo: RT, ano 7, v. 31, p. 251-261, out.-dez. 2011; FONTES, Marcos Rolim Fernandes. A arbitragem e a decretação da falência no curso do procedimento arbitral. In: Revista do Instituto dos Advogados de São Paulo, v. 23/2009, jan.-jun./2009, p. 297/311; GRION, Renato Stephan; PAIVA, Luiz Fernando Valente de; e ANDRADE SILVA, Guilherme Piccardi de. A arbitragem no contexto das recuperações judiciais e extrajudiciais e das falências. In: CAMPOS MELO, Leonardo de; e BENEDUZI, Renato Rezende. A reforma da arbitragem. Rio de Janeiro: Forense, 2016, p. 83/114; LIMA, Bernardo. Decurso simultâneo de processo falimentar e procedimento arbitral. In: Revista de Direito Recuperacional e Empresa, v. 9/2018, jul.-set./2018; MORAES, Felipe Ferreira Machado. A utilização da arbitragem por empresas em falência. Dissertação de mestrado. Pontifícia Universidade Católica de Minas Gerais. Belo Horizonte, 2014; RECHSTEINER, Beat Walter. Efeitos jurídicos da decretação da falência e da concessão da recuperação judicial em relação à arbitragem no direito brasileiro. In: LEMES, Selma M. Ferreira; CARMONA, Carlos Alberto; e MARTINS, Pedro A. Batista (coord.). Arbitragem: estudos em homenagem ao Prof. Guido Fernando Silva Soares. $1^{a}$ ed.. São Paulo: Atlas, 2007, p. 351/371; TOLEDO, Paulo F. C. Salles de. Arbitragem e insolvência. In: Revista de Arbitragem e Mediação, ano 6, n. 20, jan.-mar./2009, p. 25/52; VALENÇA FILHO, Clávio de Melo. A arbitragem em juízo. Tese de doutorado. Faculdade de Direito, Universidade de São Paulo. São Paulo, 2015; VASCONCELOS, Ronaldo; e CARNAÚBA, César Augusto Martins et al.. Financiamento de terceiros e arbitragem no processo concursal. In: Revista Brasileira de Arbitragem, v. XVI, i.61, 2019, pp. 36/62; VASCONCELOS, Ronaldo; e CARNAÚBA, César Augusto Martins. Arbitragem, insolvência e o dilema da publicidade. In: Revista de Processo, v. 292/2019, 2019, pp. 399/432. VERÇOSA, Haroldo Malheiros Duclerc. A cláusula compromissória e o art. 117, caput, da lei de recuperação de empresas e falência, $2020 . \quad$ Disponível el $<$ https://www.migalhas.com.br/dePeso/16,MI318070,61044-

A+clausula+compromissoria+e+o+art+117+caput+da+lei+de+recuperacao+de>. Acesso em: 10/jan./2020; VIEIRA, Maíra de Melo. A obrigatoriedade da cláusula compromissória em caso de litígios envolvendo empresas sujeitas a processos de falência ou recuperação. In: Revista de Arbitragem e Mediação, São Paulo: RT, ano 7, v. 28, jan.-mar. 2011. 
possibilidade de coexistência entre os institutos da falência e da arbitragem, não tendo tampouco o legislador pátrio despertado sua atenção para o assunto.

Pode-se dizer, portanto, que o tema ainda carece de uma análise mais aprofundada, principalmente à luz do direito falimentar, em que se ofereçam respostas adequadas para as diversas questões que a coexistência entre a falência e a arbitragem suscitam.

Nesse sentido, o que se propõe no presente trabalho é precisamente analisar quais são os efeitos que a falência opera sobre a arbitragem e como esses efeitos impactam na possiblidade da convivência entre os dois institutos.

Nesta tese, parte-se da hipótese de que a falência opera efeitos diretos sobre a arbitragem, impondo-lhe limites no contexto falimentar, mas que essa restrição não torna inviável a utilização. Mais especificamente, parte-se da proposição de que a falência não invalida a convenção arbitral celebrada antes da falência; não atrai nem suspende os procedimentos arbitrais em curso; mas impede a execução individualizada da sentença arbitral, a qual deve sujeitar-se ao processo concursal. Por outro lado, propõe-se também que nem a celebração da convenção de arbitragem, nem o desenvolvimento do procedimento arbitral, nem mesmo a prolação da sentença, viola a par conditio creditorium, objetivo máximo do sistema falimentar.

Para testar essas hipóteses de pesquisa, organizou-se o estudo em duas partes:

(i) Parte I, na qual se planeja apresentar algumas noções introdutórias da falência e da arbitragem relevantes para a tese proposta, que servirão para assentar as premissas e os fundamentos que serão utilizados na análise que seguirá; e

(ii) Parte II, na qual se pretende analisar os efeitos propriamente ditos da falência sobre a arbitragem, respondendo às questões suscitadas e testando as hipóteses levantadas nesta introdução.

A parte I consistirá na apresentação de algumas noções introdutórias sobre os institutos da falência e da arbitragem relevantes para a tese proposta. A apresentação será dividida em dois capítulos, nos quais se tratará, sucessivamente, da falência e da arbitragem. No capítulo 1, que versará sobre a falência, pretende-se apresentar seu conceito, natureza jurídica e alguns princípios norteadores, passar pelos efeitos que da quebra sobre a pessoa, os bens, os contratos e os processos do falido, e sobre alguns aspectos relevantes do processo falimentar, compreendendo, inclusive, o encerramento da falência. $\mathrm{O}$ trajeto empreendido 
segue lógica consignada tanto pela própria dicção da legislação falimentar quanto pela doutrina. No capítulo 2, por sua vez, que versará sobre a arbitragem, pretende-se seguir a mesma ordem de apresentação: conceito, natureza jurídica e alguns princípios norteadores, bem como pelos principais aspectos da convenção de arbitragem, do procedimento e da sentença arbitral.

A parte II, a seu turno, consistirá na análise propriamente dita dos efeitos da falência sobre a arbitragem. Esta análise será dividida em três capítulos, nos quais se tratará, sequencialmente: (i) dos efeitos da falência sobre a convenção de arbitragem; (ii) dos efeitos da falência sobre o procedimento arbitral; e (iii) dos efeitos da falência sobre a sentença arbitral.

Em primeiro lugar, a falência opera efeitos diretos sobre a pessoa, os bens e os contratos do devedor, inabilitando-o para o exercício da atividade empresarial, retirando-lhe o poder de administrar e dispor dos seus bens, e desapossando-o deles; além de garantir ao administrador judicial o direito de eleger se pretende ou não cumprir os contratos bilaterais ainda não executados. A arbitragem, por sua vez, que é contratada por meio do negócio jurídico do tipo convenção de arbitragem, também está submetida aos efeitos da lei falimentar. Diante disso, no capítulo 3, o objetivo principal será o de entender como os efeitos da falência sobre a pessoa, os bens e os contratos do devedor impactam na validade e na eficácia da convenção de arbitragem firmada antes da quebra e na possibilidade de se firmar o pacto arbitral no curso do processo falimentar. Ademais, também se buscará entender se a cláusula arbitral está submetida à regra que autoriza ao administrador judicial denunciar os contratos bilaterais não executados pelo devedor. Para tanto, o capítulo 3 será dividido em duas seções, nas quais se analisarão dois pontos principais: (i) os efeitos da falência sobre a pessoa e os bens do devedor e seu impacto na convenção de arbitragem; e (ii) os efeitos da falência sobre os contratos do devedor e seu impacto na convenção de arbitragem.

Em segundo lugar, a falência opera efeitos diretos sobre os processos do falido, provocando a atração de todas as ações envolvendo os bens (vis attractiva), interesses e negócios do falido para o juízo universal; a retirada da legitimidade processual do falido para participar dos processos relacionados à falência; e a suspensão de todas as ações e execuções em trâmite contra o devedor. Por outro lado, a arbitragem tem natureza jurisdicional, desenvolvendo-se por meio de processo de conhecimento, o qual, por sua vez, termina com a prolação de sentença, que ostenta força de título judicial. O que se pretende analisar no capítulo 4, portanto, é como os efeitos da falência sobre os processos do devedor impactam 
no desenvolvimento do procedimento arbitral, atraindo ou suspendendo os processos, além de outras questões correlatas, tais como: a manutenção da confidencialidade no curso da falência e o dever do administrador em arcar com as custas e despesas da arbitragem apesar do estado de insolvência. Para tanto, será efetuada uma divisão em quatro seções, nas quais se pretende analisar: (i) os efeitos da vis attractiva do juízo falimentar sobre o procedimento arbitral; (ii) os efeitos da regra de suspensão dos processos na falência sobre o procedimento arbitral; (iii) os efeitos da falência sobre a confidencialidade do procedimento arbitral; e (iv) os efeitos da falência sobre as custas, as despesas e os honorários de sucumbência arbitrais.

Em terceiro lugar, a falência ainda determina que todos os credores do falido convirjam para o processo falimentar para habilitarem seus créditos a fim de recebê-los de acordo com a ordem legal. Nesse cenário, pretende-se analisar no capítulo 5 se, proferida a sentença arbitral: (i) deve esta se submeter a procedimento de verificação de créditos perante o juízo falimentar; e (ii) em caso positivo, qual o conteúdo da impugnação que os participantes do processo falimentar podem apresentar.

Nas considerações finais, pretende-se organizar os resultados colhidos, testando-se as hipóteses de pesquisa, com o objetivo de apresentar respostas fundamentadas para as indagações colocadas. Ao final, serão formuladas três proposições objetivas, com a finalidade de contribuir para o debate em torno da utilização da arbitragem por empresas em crise no Brasil.

Entende-se que o trabalho é relevante do ponto do vista prático porque resolve uma série de discussões sobre a possibilidade de convivência entre os institutos da falência e da arbitragem, conferindo maior previsibilidade e segurança jurídica para o sistema jurídico brasileiro. Não se pode olvidar o fato de que, desde as respectivas edições, tanto a Lei n. 9.307, de 23 de setembro de 1996 ("Lei de Arbitragem" ou "LARB”) quanto a Lei de Recuperação de Empresas e Falências (“LREF”) vêm tendo inegável sucesso, com larga utilização no cenário nacional. É, com efeito, cada vez maior o número de empresas que adotam a arbitragem como forma de resolução de litígios, ${ }^{4}$ como também é relevante o número de empresas que recorrem ao sistema falimentar. ${ }^{5}$ Por consequência, a interação

\footnotetext{
${ }^{4}$ Pesquisa recente denominada de "Arbitragem em Números e Valores", Lemes (2018) analisa as informações divulgadas por seis das mais respeitadas das câmaras de arbitragem no Brasil, para concluir que, de 2010 a 2017 , houve aumento de mais de $114 \%$ no número de procedimentos de arbitragem iniciados, que em 2010 era de 128 e em 2017 passou para 275 novas arbitragens. Além disso, os valores envolvidos, que eram de $\mathrm{R} \$ 2,8$ bilhões em 2010, passaram para $\mathrm{R} \$ 26,30$ bilhões em 2017, o que demonstra que eles aumentaram mais que nove vezes no período.

${ }^{5}$ De acordo com o Indicador Serasa Experian de Falências e Recuperações, o número de falências requeridas nos primeiros nove meses de 2019, é de nada menos que 1100 ocorrências. Disponível em:
} 
entre os dois institutos é, também, cada vez mais frequente, como, aliás, comprova o crescente número de precedentes versando sobre o tema nos anos recentes. Ao responder às questões surgidas da coexistência entre a falência e a arbitragem, esta tese pretende contribuir para aumentar a segurança jurídica e a previsibilidade no mundo empresarial, reduzindo os custos de transação e colaborando, na ponta, para o próprio desenvolvimento econômico e social.

De modo similar, entende-se também que o trabalho é relevante do ponto de vista dogmático e efetivamente contribui para o aperfeiçoamento da ciência jurídica visto que preenche uma lacuna, verificada na atualidade, no que concerne ao estudo dos efeitos da falência sobre a arbitragem e da possibilidade de coexistência entre os dois institutos. Com efeito, passados mais de vinte anos desde a edição da Lei de Arbitragem, pode-se dizer que existe número substancial de trabalhos acadêmicos que se debruçam sobre os fundamentos do instituto e suas principais características. São, entretanto, ainda escassos os trabalhos acadêmicos que procuram avançar no estudo da arbitragem para entender em que condições se desenvolve a convivência do instituto com outras áreas do Direito. É, pois, precisamente neste contexto em que se insere o presente trabalho: procura-se suprir uma lacuna atualmente existente na academia brasileira, oferecendo-se respostas fundamentadas às questões surgidas no contexto da relação entre a arbitragem e a falência, contribuindo para o avanço do campo de estudo que pretende entender como a arbitragem se relaciona com outros institutos legais.

Por fim, é necessário advertir para as limitações do objeto desta tese. Em primeiro lugar, a pesquisa pretende analisar os impactos da falência sobre a arbitragem no contexto brasileiro, mas não se preocupa com a análise do tema sob o enfoque da arbitragem internacional ou da falência transacional, que envolve outras questões, como a escolha da lei aplicável, e demanda análise independente. Sem prejuízo, no curso do trabalho se recorrerá, em sede estrangeira, tanto à doutrina quanto à jurisprudência arbitral e estatal, com a finalidade de trazer novos elementos para a discussão. Foram colhidos excertos doutrinários e jurisprudenciais, principalmente, da França, da Inglaterra, dos Estados Unidos da América, da Alemanha e de Portugal, porque tratam-se de países com tradição consolidada no contexto da arbitragem, nos quais já houve oportunidade de debater a questão da inter-relação desse instituto com a falência. Em segundo lugar, a pesquisa analisa os impactos da falência sobre a arbitragem, mas não examina a mesma questão no contexto da recuperação judicial, 
extrajudicial e das liquidações extrajudiciais. Estes assuntos, afinal, submetem-se a lógica e a regras próprias, as quais também demandam análise destacada. E em terceiro lugar, o trabalho se ocupa da correlação específica entre a arbitragem e a falência, mas não cuida dos casos de insolvência individual, que não é regida, no Direito brasileiro, pela LREF, mas pelo Código Civil, merecendo, do mesmo modo, estudo autônomo.

Com essas considerações preliminares, passa-se ao trabalho. 


\section{CONSIDERAÇÕES FINAIS}

\section{Síntese dos achados de pesquisa}

Esta tese teve como escopo a análise dos efeitos da falência sobre a arbitragem. Partiu-se da hipótese de que a falência, apesar de operar efeitos sobre a arbitragem, não torna inviável a coexistência entre os dois institutos. Para testar a hipótese de pesquisa, o trabalho foi dividido em duas grandes partes: (i) na parte I, tratou-se de apresentar algumas noções introdutórias sobre os institutos da falência e da arbitragem, com a finalidade de fixar as premissas que serviram de base para a análise a ser realizada na parte II; e (ii) na parte II, cuidou-se de analisar os efeitos propriamente ditos da falência sobre a arbitragem, com o fito de avaliar a possibilidade de coexistência entre os dois institutos.

A parte I, dedicada a definir os conceitos e as premissas relevantes para a tese proposta, foi dividida em dois capítulos, nos quais foram apresentadas, sucessivamente, (i) noções introdutórias sobre a falência e (ii) noções introdutórias sobre a arbitragem. A parte II, a seu turno, cuidando da análise propriamente dita dos efeitos da falência sobre a arbitragem, foi dividida em três capítulos, nos quais se cuidou, na seguinte sequência: (i) dos efeitos da falência sobre a convenção de arbitragem; (ii) dos efeitos da falência sobre o procedimento arbitral; e (iii) dos efeitos da falência sobre a sentença arbitral.

\section{$\underline{\text { Parte I }}$}

Esta parte analisou, em separado, os institutos da falência e da arbitragem. Viu-se, de especial importância para o presente trabalho, que a falência:

(i) constitui um regime complexo, formado por regras materiais e processuais, criado para lidar com o problema da insolvência empresarial, por meio do qual procede-se à liquidação organizada dos ativos do devedor para pagar seus credores de acordo com a ordem legal;

(ii) tem como objetivos o pagamento dos credores do falido, respeitada a máxima da par conditio creditorium, e o saneamento do mercado, com impacto no crédito em geral, congregando, pois, além de interesses privados, interesses de ordem pública; 
(iii) apresenta natureza de execução coletiva, reunindo todos os credores do falido e todos os seus bens e direitos, os quais devem ser liquidados e seu produto repartido nos termos da lei;

(iv) orienta-se pelos princípios da igualdade entre os credores, da unidade e universalidade do juízo falimentar, da economia e celeridade processual, da viabilidade e maximização do valor dos ativos do falido, e da publicidade;

(v) para dar consecução aos seus objetivos, opera efeitos diretos sobre a pessoa do devedor, seus bens, seus contratos e seus processos: (a) inabilitando o falido para o exercício da atividade empresarial; (b) retirando do falido o poder de administrar e de dispor dos seus bens; (c) garantindo ao administrador judicial a prerrogativa de resolver os contratos bilaterais firmados, mas ainda não executados, pelo falido; (d) determinando a atração (vis attractiva) das ações envolvendo os bens e direitos do falido para o juízo falimentar; (e) decretando a suspensão de todas as ações e execuções contra o devedor; e (f) tornando obrigatória a submissão de todos os créditos contra o falido à processo de verificação perante o juízo falimentar;

(vi) realiza-se por meio de procedimento administrado pelo Poder Judiciário, centralizado, público, por meio do qual serão, de um lado, verificados e incluídos no quadro geral de credores todos os créditos contra o falido; e, de outro, arrecadados e liquidados todos os seus ativos; e

(vii) se encerra com a prolação de sentença, o que não implica na extinção das obrigações falido, nem da sua personalidade jurídica, que podem sobreviver ao processo falimentar.

Por outro lado, também se viu que a arbitragem:

(i) é meio privado de solução de controvérsias por meio do qual partes capazes elegem um terceiro, da sua confiança, para resolver litígio versando sobre direitos patrimoniais disponíveis; 
(ii) orienta-se pelos princípios da autonomia da vontade, da autonomia da convenção de arbitragem, Kompetenz-Kompetenz e do devido processo legal;

(iii) é contratada por meio do negócio jurídico do tipo "convenção arbitral”, que tem natureza de negócio jurídico plurilateral, e só pode ser firmado por partes capazes e versar sobre direitos patrimoniais disponíveis;

(iv) uma vez contratada, é vinculativa, produz efeitos desde a contratação e afasta a jurisdição do Poder Judiciário para dirimir o mérito da controvérsia;

(v) desenvolve-se por meio de processo jurisdicional, mas restringe-se à fase de conhecimento, detendo os árbitros os poderes de conhecer e dizer o direito, mas não de substituir a vontade do jurisdicionado para fazer cumprir sua decisão;

(vi) realiza-se por meio de procedimento descentralizado, privado, remunerado, usualmente sigiloso, no qual as partes têm ampla liberdade para definir as regras materiais e processuais aplicáveis; e

(vii) se encerra com a prolação da sentença arbitral, a qual não se sujeita à recurso e tem força de título judicial.

Com ambos os institutos - falência e arbitragem - assentados,, foi então possível passar a análise propriamente dita dos efeitos da falência sobre a arbitragem.

\section{$\underline{\text { Parte II }}$}

Na parte II, por sua vez, foram analisados os efeitos da falência sobre a arbitragem. Dada a complexidade do assunto, a análise foi repartida em três capítulos, tratando: (i) da convenção de arbitragem; (ii) do procedimento arbitral; e (iii) da sentença arbitral.

As principais conclusões alcançadas nesta segunda parte da pesquisa serão sintetizadas a seguir: 


\section{Dos efeitos da falência sobre a convenção de arbitragem}

No capítulo 3, foram analisados os efeitos da falência sobre a convenção de arbitragem. A análise foi dividida em duas seções, nas quais se cuidou, respectivamente, (i) dos efeitos da falência sobre a pessoa e os bens do falido e seu impacto na convenção de arbitragem; e (ii) dos efeitos da falência sobre os contratos do falido e seu impacto na convenção de arbitragem.

A seguir, arrolam-se as principais conclusões encontradas na pesquisa quanto a este subtema.

Dos efeitos da falência sobre a pessoa e os bens do falido e seu impacto na convencão de arbitragem

O primeiro ponto analisado foram os efeitos da falência sobre a pessoa e os bens do falido e o seu impacto para a convenção de arbitragem.

A primeira conclusão é de que a convenção de arbitragem firmada pelo falido antes do decreto de quebra permanece, depois da falência, válida e eficaz. O decreto de falência inabilita o falido para o exercício da atividade empresarial e retira dele a legitimidade para administrar e dispor dos seus bens, mas não afeta a capacidade jurídica, que permanece hígida durante - e sobrevive a - todo o processo falimentar. Além disso, o decreto de falência tampouco torna os bens do falido indisponíveis. É o falido que perde a legitimidade para administrar e dispor dos seus bens, a qual passa para o administrador judicial. Isso, contudo, não altera a natureza dos bens, que, se eram disponíveis antes do decreto falimentar, assim continuarão a ser. Portanto, em nada se passando com a capacidade jurídica do falido e tampouco com disponibilidade dos seus bens, a convenção de arbitragem firmada pelo falido antes do decreto de quebra permanece válida e eficaz. Equivoca-se, pois, a jurisprudência nacional ao concluir pela validade da convenção de arbitragem com o fundamento de que o pacto foi firmado antes da falência, quando as partes ainda eram capazes. Se nada ocorre com a capacidade do falido, o fato de a convenção ter sido firmada antes da quebra não é decisivo para a discussão.

A segunda conclusão é de que a convenção de arbitragem firmada pelo falido depois do decreto de quebra é válida, mas inoponível em relação à massa. $\mathrm{O}$ falido, com o decreto de falência, perde a legitimidade para administrar e dispor dos seus bens e direitos. Por sua vez, os atos praticados quem não detém legitimidade para praticá-los não são inválidos, mas 
apenas ineficazes. No caso da falência, portanto, quando o falido pratica um ato versando sobre os bens e direitos submetidos ao concurso, dos quais é proprietário, mas em relação aos quais perdeu a legitimidade para dispor, esse ato é válido, mas ineficaz. Essa ineficácia, por sua vez, é relativa, porque o ato produz efeitos entre as partes contratantes, mas é inoponível em relação ao administrador judicial. Se, pois, o falido, após o advento da quebra, firmar uma convenção de arbitragem versando sobre os bens e direitos submetidos ao concurso, esse negócio será válido e eficaz entre as partes contratantes, mas ineficaz em relação à massa.

A terceira conclusão é de que a convenção de arbitragem firmada pelo administrador judicial depois do decreto de quebra é válida e eficaz, mas depende de autorização judicial. Com a perda pelo falido do poder de administrar e dispor dos seus bens, a prerrogativa se transfere para o administrador judicial, o qual, por sua vez, pode praticar todos os atos para a realização do ativo, o pagamento dos credores e a conservação dos direitos e ações da massa, observados os limites legais. Se a LREF autoriza o administrador judicial, na condição de titular do poder de administração e disposição dos bens do falido, a praticar todos os referidos atos, que são conceitos bastante amplos, não se vê por que, apesar de não estar expresso na lei, não se inseriria nessas prerrogativas a de firmar o negócio jurídico do tipo convenção de arbitragem, desde que para cumprir os objetivos da LREF (isto é, desde que evidencie que a convenção de arbitragem pode trazer benefícios para a massa) e observados os limites legais. Registre-se que quem firmará a convenção de arbitragem é o administrador judicial, em nome próprio, na condição de titular do poder de administrar e dispor do patrimônio do falido, e não a massa falida, que não é sujeito, mas objeto de direito. A LREF prevê em diversos dispositivos a necessidade de obtenção, pelo administrador, de autorização judicial para a prática de atos em geral que tenham potencial de onerar ou criar despesas para a massa. Como a celebração da convenção de arbitragem importa na assunção da obrigação de realizar despesas, pode-se concluir que, também para a celebração de uma convenção de arbitragem, o administrador judicial deve obter autorização judicial. A falta desse requisito, por constituir requisito de validade, torna nulo o negócio. Por fim, não é o caso de se exigir a autorização do comitê de credores para celebração da convenção de arbitragem. O comitê de credores deve ser ouvido em diversas ocasiões da lei falimentar, mas a LREF só exige a obtenção de autorização prévia dele nos casos dos atos de oneração ou disposição dos bens e direitos da massa (LREF, art. 99, VI) e quando se pretende dar cumprimento aos contratos bilaterais (LREF, art. 117). Como, ao firmar uma convenção de arbitragem, não se está praticando nenhum ato de disposição de direito, mas meramente se 
assumindo obrigação de dar consistente no pagamento das custas e despesas arbitrais (isto é, criando uma despesa para a massa), não é o caso de se exigir a autorização do Comitê para celebração do pacto arbitral. Basta a autorização judicial.

\section{Dos efeitos da falência sobre os contratos do falido e a convencão de arbitragem}

O segundo ponto analisado foram os efeitos da falência sobre os contratos do falido e seus impactos para a convenção de arbitragem.

A primeira conclusão é de que a submissão da convenção de arbitragem à regra do art. 117 da LREF deve ser analisada de forma autônoma e independente em relação ao contrato em que está inserida. A convenção de arbitragem é negócio distinto do negócio principal, submetendo-se a regime jurídico próprio, de modo que também assim — de forma segregada - deve ser feita a análise dos impactos da regra do art. 117 da LREF sobre a validade e eficácia da cláusula arbitral.

A segunda conclusão é de que a convenção de arbitragem não se submete à regra do art. 117 da LREF porque não tem natureza de contrato bilateral. A regra do art. 117 da LREF está voltada para os contratos bilaterais, assim entendidos os negócios jurídicos em que as partes assumem obrigações contrapostas, recíprocas e dependentes uma da outra. A convenção de arbitragem, todavia, tem natureza de negócio plurilateral, em que as manifestações de vontade das partes são paralelas e convergem para o fim comum, que é resolver seus litígios por meio da arbitragem. Não se afigurando como contrato bilateral, à convenção de arbitragem não é aplicável à regra do art. 117 da LREF. Além disso, a referida regra volta-se para os negócios jurídicos que envolvam atribuição patrimonial, podendo gerar ganhos ou perdas para a massa. Sendo, entretanto, a convenção de arbitragem negócio jurídico que não envolve em si atribuição patrimonial, mas tem natureza colaborativa, instrumental, que não implica a circulação de riqueza, não se pode cogitar de aplicar ao pacto arbitral a regra do art. 117 da LREF.

A terceira conclusão é de que a convenção de arbitragem não se submete à regra do art. 117 da LREF porque produz efeitos desde a sua assinatura. A regra do art. 117 da LREF tem aplicação restrita aos contratos bilaterais ainda não executados quando da decretação da falência. Por meio da convenção de arbitragem, contudo, as partes assumem reciprocamente, entre outras obrigações, a de não fazer consistente em não ingressar no Poder Judiciário para resolver litígio abrangido pelo pacto arbitral, a qual produz efeitos desde o momento da contratação. Além disso, essa obrigação de não fazer, apesar de ser "de duração", é do tipo 
indivisível, não se podendo fracioná-la no tempo para segregar os atos praticados no passado. Se, portanto, a LREF autoriza o administrador judicial a não cumprir os contratos bilaterais cuja execução ainda não tenha se iniciado, mas se, por outro lado, a convenção de arbitragem já produz efeitos desde o momento da contratação, não se podendo fracioná-los no tempo, pode-se concluir que não se afigura possível aplicar a regra do art. 117 da LREF aos pactos arbitrais, que, mesmo após o advento da falência, permanece válido e eficaz.

\section{Dos efeitos da falência sobre o procedimento arbitral}

No capítulo 4, por sua vez, foram analisados os efeitos da falência sobre o procedimento de arbitragem. A análise foi dividida em quatro seções, nas quais cuidou-se, respectivamente: (i) dos efeitos da vis attractiva do juízo falimentar sobre o procedimento arbitral; (ii) dos efeitos da regra de suspensão dos processos na falência sobre o procedimento arbitral; (iii) dos efeitos da falência sobre a confidencialidade do procedimento arbitral; e (iv) dos efeitos da falência sobre as custas, despesas e honorários arbitrais. A seguir, as principais conclusões encontradas na pesquisa.

\section{Dos efeitos da vis attractiva do juízo falimentar sobre o procedimento arbitral}

O primeiro ponto analisado foram os efeitos da vis attractiva do juízo falimentar sobre o procedimento arbitral.

A primeira conclusão é de que as arbitragens não são atraídas para o juízo falimentar porque têm natureza cognitiva. A regra do art. 76 da LREF fixa a universalidade do juízo falimentar. A finalidade da regra é reunir todos os credores do falido, bem como todos os seus bens e direitos, dando vigência à par conditio creditorium. Porque, entretanto, não apresentam riscos para a igualdade dos credores, estão excluídas desta regra, nos termos previstos no $\S 1^{\circ}$ do art. $6^{\circ}$ da LREF, as ações de conhecimento em geral, abrangendo-se tanto as ações já existentes no momento da decretação da falência quanto as ajuizadas posteriormente. A arbitragem, por sua vez, tem natureza de processo de conhecimento, detendo os árbitros os poderes de conhecer e de dizer o direito, bem como o de coagir as partes ao cumprimento das suas ordens pelos meios que visam influir sobre a sua vontade, sem dispor, contudo, dos chamados meios de sub-rogação, ou de substituição da vontade do obrigado, mediante o emprego da força e da constrição, reservados aos juízes estatais. Desse modo, se se excepcionam da regra de concentração dos processos no juízo falimentar as 
ações de conhecimento em geral, e se a arbitragem desenvolve-se sempre - e somente através de processo de conhecimento, pode-se concluir que a regra do art. 76 da LREF não se aplica às arbitragens. Os procedimentos arbitrais podem continuar a tramitar regularmente mesmo no curso do processo falimentar, devendo os títulos resultantes desses procedimentos ser apresentados na falência para verificação. Isso, deve-se dizer, vale tanto para as arbitragens em curso quanto para as arbitragens iniciadas após o decreto falimentar. Devese atentar, contudo, que o árbitro não poderá tomar nenhuma medida que possa a denegrir a igualdade no tratamento dos credores do falido; e que não serão arbitráveis as causas reguladas na lei falimentar, para as quais, por motivos de interesse público, o legislador expressamente reservou a jurisdição para o juízo universal.

A segunda conclusão é de que o administrador judicial, agindo em nome próprio, deve substituir o falido nos procedimentos arbitrais, sob pena de nulidade. Por conta da perda, pelo falido, da legitimidade para administrar e dispor do seu patrimônio, ele perde também a legitimidade processual para figurar como parte nos processos envolvendo os bens e direitos da massa falida. Essa legitimidade, tanto material quanto processual, passa não para a massa falida — que é um complexo de bens e direitos, não um sujeito de direito —, mas para o administrador judicial, que deve exercê-la, sob supervisão judicial e do comitê de credores, para cumprir os objetivos da lei. O administrador judicial, por sua vez, que não é representante de ninguém, mas órgão auxiliar do juízo criado por lei, atua, na condição de detentor da legitimidade material e processual dos bens e direitos do falido, em nome próprio, como substituto processual do falido por força de disposição expressa de lei. A não efetivação da substituição processual gera a nulidade do processo por falta de condição da ação, o que, no caso da arbitragem, conduzirá à nulidade da sentença arbitral por inobservância de norma imperativa de ordem pública. Não é o caso de sub-rogação material da massa falida, ou do administrador judicial, na convenção de arbitragem. O decreto de falência não extingue a personalidade jurídica do devedor, não lhe retira a propriedade dos bens e direitos, nem transfere a propriedades desses para um novo sujeito. Há, apenas e tão somente, a perda da legitimidade para administrar e dispor dos seus bens e direitos, e a perda da legitimidade para figurar como parte nos processos correspondentes. As obrigações e direitos contraídos pelo falido anteriormente à falência, entretanto, permanecem tendo nele — o falido - o seu centro de imputação. Assim, apesar da substituição do falido pelo administrador judicial nos processos, fenômeno que opera no mundo do direito processual, isso não interfere na relação de direito material entre o falido e a contraparte na arbitragem, que são efetivamente aqueles que devem estar vinculados à convenção arbitral. 
A terceira conclusão é de que o falido tem legitimidade para intervir como assistente nos procedimentos arbitrais. Como a sentença que será proferida nos processos envolvendo o administrador judicial irá, necessariamente, produzir efeitos diretos na esfera jurídica do falido, tem ele - o falido - interesse jurídico para figurar como assistente em todos os processos envolvendo os bens e direitos submetidos ao concurso, para defender os próprios interesses. E se assim é, deve ter o falido, também, o mesmo interesse jurídico de participar de todos os procedimentos arbitrais de que o administrador judicial seja parte. Entender de outro modo seria negar ao falido o direito de defender seus interesses em juízo, em situação de denegação de justiça.

A quarta conclusão é de que o Ministério Público não participa das arbitragens. A LREF reserva a participação do membro do Ministério Público às hipóteses especificas delineadas na lei, dentre as quais não se incluem as ações de conhecimento movidas contra ou a favor do devedor. Além disso, o Ministério Público poderá intervir em todos os processos, desde que envolvam interesse público ou direitos indisponíveis. A arbitragem, todavia, é processo de conhecimento e se restringe aos direitos patrimoniais disponíveis. Assim sendo, infere-se diretamente que o Ministério Público não tem legitimidade para intervir nas arbitragens em curso envolvendo o falido. A atuação do membro do Parquet ficará reservada para o momento de verificação e de inclusão do crédito representado pela respectiva sentença arbitral no quadro geral de credores. Ressalve-se somente o caso das ações reguladas na LREF, que, apesar de contar com a participação do Ministério Público, nos termos da LREF, não podem ser submetidas à arbitragem, visto que o Estado reservou para si a exclusividade da jurisdição.

Dos efeitos da regra de suspensão dos processos na falência sobre o procedimento arbitral

O segundo ponto analisado foi a regra de suspensão dos processos na falência e seus impactos para a convenção de arbitragem.

A primeira conclusão é de que as arbitragens não são suspensas com o decreto de quebra do falido porque têm natureza cognitiva. ${ }^{662}$ A regra do art. $6^{\circ}$ da LREF determina a suspensão de todas as ações e execuções contra o falido. A finalidade da regra, assim como a universalidade, é de reunir todos os credores do falido no juízo falimentar, dando vigência

${ }^{662}$ A análise, aqui, espelha a conclusão alcançada quando do estudo dos efeitos da vis attractiva do processo falimentar sobre os procedimentos arbitrais. 
à par conditio creditorium. Porque, entretanto, não apresentam riscos para a igualdade dos credores, estão excluídas dessa regra, nos termos previstos no $\S 1^{\circ}$ do art. $6^{\circ}$ da LREF, as ações de conhecimento em geral. A arbitragem, por sua vez, tem natureza de processo de conhecimento, detendo os árbitros os poderes de conhecer e dizer o direito, mas não dispondo dos meios de sub-rogação mediante o emprego da força e da constrição. Desse modo, se excluem-se da regra de suspensão dos processos no juízo falimentar as ações de conhecimento em geral, e se a arbitragem desenvolve-se sempre por meio de processo de conhecimento, disso se aduz que a regra do art. $6^{\circ}$ da LREF não se aplica às arbitragens. Os procedimentos arbitrais podem continuar a tramitar regularmente mesmo no curso do processo falimentar, devendo os títulos que resultarão desses procedimentos ser apresentados na falência. Isso, deve-se dizer, vale tanto para as arbitragens em curso quanto para as arbitragens iniciadas após o decreto falimentar.

A segunda conclusão é de que o árbitro tem competência para decidir sobre pedido de reserva do art. $6^{\circ}, \S 3^{\circ}$, da LREF, mas sua decisão pode ser recusada pelo juízo falimentar em casos excepcionais. De acordo com a lei falimentar, é cabível à parte de uma ação que demande quantia ilíquida realizar pedido de reserva de valores na falência. Este pedido deve ser formulado perante o juízo competente para processar a demanda, e não perante o juízo universal. E se assim é, o mesmo deve ocorrer nas arbitragens: a parte pode requerer ao tribunal arbitral a reserva dos valores que estimar como devidos, que proferirá decisão, requerendo o cumprimento desta pelo juízo universal por carta arbitral, nos termos do art. 22-C da LARB. Relevante registrar que, nesses casos, não cabe ao juízo falimentar rever o mérito da decisão arbitral, que deve ser cumprida, como ocorre em todos os demais casos de cooperação entre a arbitragem e o Poder Judiciário. Cabe, no entanto, como em qualquer carta arbitral, analisar se existem vícios formais, ou violação à ordem pública, como também se a carta arbitral não incorre em nenhum dos vícios prescritos no art. 32 da LARB.

\section{Dos efeitos da falência sobre a confidencialidade do procedimento arbitral}

O terceiro ponto analisado foram os efeitos da falência sobre a confidencialidade do processo arbitral.

A primeira conclusão é de que as arbitragens envolvendo os bens e direitos do falido se mantêm privadas, mas o falido e o administrador judicial têm o dever de prestar, na falência, as informações necessárias para o desenvolvimento do processo falimentar. A arbitragem, apesar de ser usualmente confidencial, pode ter o traço do sigilo mitigado em 
face de outros interesses relevantes que se sobreponham. Se assim é, no caso de a arbitragem envolver os bens e interesses do falido, a confidencialidade deverá, em caso de impossibilidade de coexistência com os princípios do Direito Falimentar, ceder em favor da publicidade. Como, entretanto, a arbitragem tem natureza cognitiva e termina com a prolação de sentença, que deverá ser habilitada no processo falimentar — o qual, por sua vez, tem natureza de execução coletiva e se preocupa com os créditos já constituídos em face do falido —, não há impossibilidade de coexistência a justificar a eliminação por completo da confidencialidade da arbitragem em favor da falência. A arbitragem seguirá em sigilo, normalmente, até a prolação da sentença arbitral, a qual, então, deverá ser apresentada na falência para inclusão no quadro geral de credores. Essa regra, contudo, não é absoluta. Nos termos da lei falimentar, tanto o falido quanto o administrador judicial têm o dever de informar ao juízo falimentar sobre a existência ou sobre o início de qualquer processo envolvendo os bens e direitos do falido. Assim, apesar de a arbitragem se manter privada, tanto o falido quanto o administrador judicial têm o dever de informar ao juízo falimentar sobre a existência do processo, com informações mínimas que permitam aos participantes da falência avaliar o impacto da demanda para o processo concursal. Por outro lado, tanto o juízo falimentar quanto o comitê de credores têm a função de fiscalizar as atividades do administrador judicial, de zelar pelo bom andamento do processo falimentar e de cuidar para que não ocorram violações aos direitos ou prejuízos aos interesses dos credores. Assim, quando, no exercício das suas funções, o juízo falimentar ou o comitê de credores solicitarem ao falido, ou ao administrador judicial, qualquer informação adicional com relação a arbitragem, estarão estes obrigados, nos termos dos arts. 104, VI, e 22, I, "b”, da LREF, a repassar essas informações. Nesse caso, não há restrição para os pedidos do juízo falimentar e do comitê de credores, bastando justificar o pedido tomando por base a razoabilidade. A informação, contudo, não deverá ser de pronto publicada no processo falimentar. O juízo falimentar pode funcionar, nesses casos, como um filtro para apreciar os interesses conflitantes. Se entender que dar conhecimento da informação aos participantes do processo falimentar é necessário para que eles possam exercer seus direitos, optará o juízo universal pela mitigação da confidencialidade. Caso contrário, mantém-se a informação em sigilo, restrita ao conhecimento do juízo falimentar. Desse modo, preserva-se a privacidade do procedimento de arbitragem, ao mesmo tempo que se atende às exigências do processo falimentar.

A segunda conclusão é de que a sentença arbitral se tornará pública no contexto do processo falimentar. Nos termos da LREF, todos os créditos contra o falido devem submeter- 
se a procedimento de verificação de créditos na falência, sendo passíveis de serem impugnados pelo falido, pelo comitê de credores, por qualquer credor e pelo Ministério Público. Se não impugnado, ou se rejeitada a impugnação, esse crédito será incluído no quadro geral de credores da falência para recebimento de acordo com a ordem legal. Contra essa inclusão, cabe ainda a apresentação da ação rescisória do art. 19 da LREF, com a finalidade de rescindir a decisão que homologou o quadro geral, pelos mesmos legitimados para interpor a impugnação. Por conta disso, todos os participantes do processo falimentar, aí incluídos o falido, o Comitê, seus credores, o administrador judicial e o membro do Ministério Público, devem ter conhecimento da sentença arbitral - título que representa o crédito que se pretende incluir no quadro geral - para exercer seus direitos, inclusive o de se insurgir contra a pretensão de inclusão deste crédito na falência. $O$ interesse de tornar conhecida a sentença arbitral para os participantes do processo de falência permanece, seja nas arbitragens em que o administrador judicial figure como autor, seja nos em que atue como réu. Em ambos os casos, a vitória ou derrota no processo tem o condão de influir diretamente nas decisões que serão tomadas no curso do processo de falência, justificando a sua divulgação para os interessados. Além disso, todo o conteúdo da sentença deve ser apresentado aos participantes do processo falimentar. No caso da sentença arbitral, portanto, a confidencialidade deverá ser mitigada.

\section{Dos efeitos da falência sobre as custas, despesas e honorários de sucumbência do procedimento arbitral}

O quarto ponto analisado foram os efeitos da falência sobre as custas, despesas e honorários de sucumbência do procedimento arbitral.

A primeira conclusão é de que o administrador judicial está obrigado a pagar as custas arbitrais, mas a falta de recursos para fazê-lo pode tornar a convenção de arbitragem inexequível. O princípio do acesso à justiça dita que o Estado não poderá excluir nenhuma lesão ou ameaça a direito da apreciação do Poder Judiciário. Se, firmada uma convenção arbitral, a parte vier posteriormente a cair em insolvência, não podendo arcar com as custas arbitrais, uma eventual recusa do Poder Judiciário em apreciar a controvérsia acabará por deixar a parte impecuniosa sem acesso a nenhuma prestação jurisdicional, em situação de denegação de justiça. Por isso, se uma parte firma uma convenção de arbitragem, mas posteriormente tem a sua quebra decretada e fica sem recursos para arcar com as custas arbitrais, deve-se mitigar o efeito negativo da convenção de arbitragem para permitir que as 
partes submetam sua disputa ao Poder Judiciário. Trata-se de causa de inexequibilidade da convenção de arbitragem, espécie de meio de resolução da obrigação em decorrência da impossibilidade fática de seu cumprimento por fato não imputável às partes. Para que se configure a inexequibilidade da convenção de arbitragem, o falido deve comprovar a ausência de recursos e a inexistência de outros meios que permitam a solução do impasse. O estado de falência, apesar de constituir evidência de dificuldade financeira, não cria uma presunção a autorizar per se a desconsideração da convenção de arbitragem. Deve-se proceder à análise específica da situação concreta, para saber se a falta de recursos é tamanha, que efetivamente impede a parte de obter a prestação jurisdicional, afigurando-se a impecuniosidade, somente neste caso, em causa de inexequibilidade da convenção arbitral.

A segunda conclusão é de que, em caso de alegação de inexequibilidade da convenção de arbitragem pela falta de recursos, deve-se mitigar o efeito negativo do princípio competência-competência para autorizar o Poder Judiciário a ingressar no mérito e proferir decisão sobre a questão. No Direito brasileiro, vigora o princípio competênciacompetência, segundo o qual cabe aos árbitros, em primeiro lugar, analisar as questões relacionadas à existência, à validade e à eficácia da convenção de arbitragem, restringindose atuação do Poder Judiciário à fase de anulação/execução da sentença. Em casos extraordinários, entretanto, admite-se a mitigação do efeito negativo do princípio competência-competência, para que o Poder Judiciário possa analisar as questões relativas à existência, à validade e à eficácia do pacto arbitral, sem aguardar a análise dos árbitros. No caso da alegação da parte falida sobre a falta de recursos para iniciar um procedimento arbitral, se a alegação for verdadeira, a recusa do Poder Judiciário em analisar a questão irá deixá-la sem acesso nem ao Poder Judiciário nem à solução arbitral, criando-se situação de denegação de justiça. Assim, considerando a impossibilidade prática, no caso de alegação de falta de recursos, de se dar início ao procedimento de arbitragem, deve-se também mitigar o efeito negativo do princípio competência-competência para permitir que o Poder Judiciário analise a alegação de inexequibilidade da convenção arbitral no caso de a parte falida não dispor de nenhum meio de arcar com a sua parcela das custas da arbitragem. A situação será diferente, entretanto, se a parte falida impecuniosa for ré, não autora do procedimento arbitral. Nesse caso, a contraparte não falida possivelmente irá adiantar a totalidade das custas arbitrais de modo a dar início ou prosseguimento ao procedimento de arbitragem. Se, na hipótese, a parte falida tiver formulado pedido reconvencional, o tribunal deverá analisar se exclusão desse pedido pode prejudicar o direito de defesa do falido, caso em que, mesmo sem o pagamento das custas, não será possível descartar o pedido, que deverá ser apreciado. 
Nos demais casos, o tribunal arbitral estará liberado para excluir os pedidos reconvencionais da arbitragem, mas a parte inadimplente poderá valer-se do Poder Judiciário para iniciar demanda própria e formular os pedidos que não foram apreciados pelo tribunal arbitral

A terceira conclusão é de que o administrador judicial deve pedir autorização do juízo falimentar para realizar o pagamento das custas arbitrais. A LREF prevê que o administrador judicial pode praticar, no curso do processo falimentar, todos os atos conservatórios de direitos e ações, mas sempre que for contratar auxiliares ou avaliadores (isto é, sempre que for contratar serviços que venham a onerar a massa falida), deve fazê-lo mediante autorização judicial. Ademais, além da contratação, também a efetiva fixação do valor da despesa deve passar pelo crivo judicial. No caso da arbitragem, a fixação das custas arbitrais fica a cargo das câmaras de arbitragem, não sendo fixáveis pelo juízo universal. Em todo caso, em sendo a despesa usualmente de valor bastante relevante, parece razoável que o seu pagamento seja previamente submetido à apreciação judicial, que, apesar de não opinar sobre a fixação do valor, ao menos poderá tomar conhecimento da necessidade de realização da despesa e autorizar a sua realização. Se o fizer sem autorização judicial, deve ser capaz de comprovar, nos termos do art. 150 da LREF, que o pagamento era indispensável para a administração da falência, e que não podia esperar por autorização judicial, sob pena de responder pelas perdas causadas.

A quarta conclusão é de que o mesmo tratamento dispensado pela LREF às custas, às despesas e aos honorários de sucumbência no processo civil ordinário deve ser aplicado às custas, às despesas e aos honorários arbitrais. Os conceitos de custas arbitrais, despesas arbitrais e honorários de sucumbência em sede arbitral se equiparam aos conceitos dos mesmos institutos em sede judicial. Não havendo diferença no tratamento dos institutos em sede judicial e arbitral, o mesmo tratamento conferido pela LREF aos institutos judiciais deve ser transposto para a sede arbitral. Assim: (i) são exigíveis do devedor as custas arbitrais relativas às ações contra o falido e contra o administrador judicial (as incorridas anteriormente à decretação da quebra constituem créditos quirografários, ao passo que as surgidas nas ações posteriores à quebra ostentam natureza extraconcursal); (ii) são exigíveis do devedor as despesas arbitrais relativas às ações contra o falido e o administrador judicial (as incorridas anteriormente à decretação da quebra constituem créditos quirografários, ao passo que as surgidas nas ações posteriores à quebra ostentam natureza extraconcursal); e (iii) são exigíveis do devedor os honorários de sucumbência arbitrais relativos às ações contra o falido e o administrador judicial (os incorridos anteriormente à decretação da quebra constituem créditos quirografários, mas têm natureza alimentar até o limite de 150 salários 
mínimos, ao passo que os surgidos nas ações posteriores à quebra ostentam natureza extraconcursal).

\section{$\underline{\text { Dos efeitos da falência sobre a sentenca arbitral }}$}

Por fim, no capítulo 5, foram analisados os efeitos da falência sobre a sentença arbitral. A análise foi dividida em duas seções, nas quais se questionou se, proferida a sentença arbitral, (i) deve esta se submeter a procedimento de verificação de créditos perante o juízo falimentar; e (ii) em caso positivo, qual o conteúdo da impugnação que os participantes do processo falimentar podem apresentar.

\section{Os créditos representados por sentenca arbitral devem submeter-se ao processo de}

\section{verificacão de créditos na falência}

O primeiro ponto analisado foi a necessidade de submissão dos créditos representados por sentença arbitral ao processo de verificação de créditos em sede falimentar.

A conclusão é de que os créditos representados por sentença arbitral devem submeter-se ao processo de verificação de créditos na falência. Todos os créditos contra o falido, mesmo os representados por títulos judiciais, devem submeter-se ao processo de verificação de créditos na falência. E, se assim é para os créditos representados por títulos judiciais em geral, assim também deve ser para os créditos representados por sentenças arbitrais, cujos efeitos se equiparam às primeiras. As sentenças arbitrais, portanto, sejam as proferidas antes ou depois do decreto falimentar, devem necessariamente se submeter a procedimento de verificação de créditos na falência, garantindo-se aos demais participantes do processo o direito de se insurgir, se for o caso, contra a pretensão de inclusão da sentença no quadro geral.

\section{O conteúdo da impugnacão de crédito no caso de crédito representado por sentenca} arbitral fica restrito às matérias constantes dos arts. 525, $\S 1^{\circ}$, do CPC, e 32 da LARB

O segundo ponto analisado foi o conteúdo da impugnação falimentar.

A conclusão é que o conteúdo da impugnação de crédito no caso de crédito representado por sentença arbitral deve restringir-se às matérias previstas no art. $525, \S 1^{\circ}$, 
do CPC, bem como àquelas descritas no art. 32 da LARB. Todos os créditos representados por títulos judiciais podem ser impugnados no âmbito falimentar, mas o conteúdo da impugnação deve restringir-se às matérias arguíveis em sede de impugnação ao cumprimento de sentença. Os créditos representados por sentença arbitral, por equipararemse à sentença judicial, também só poderão ser atacados no fundamento nas causas de impugnação ao cumprimento de sentença. No caso da sentença arbitral, contudo, sua nulidade também pode ser arguida com fundamento no disposto no art. 32 da LARB. Assim, no caso dos créditos representados por sentença arbitral, deve-se acrescentar às causas de impugnação aplicáveis aos títulos judiciais em geral também as causas de impugnação arguíveis em sede de impugnação ao cumprimento da sentença arbitral, como matérias arguíveis em sede de impugnação falimentar.

$* * * * * * * * * *$

Confirma-se, pois, parcialmente a hipótese de pesquisa levantada na introdução: de fato, a falência opera efeitos diretos sobre a arbitragem, a esta impondo limites no contexto falimentar, mas isso não torna inviável a utilização do instituto arbitral.

Mais especificamente, confirma-se a ideia de que a falência não invalida a convenção arbitral celebrada antes da falência, mas acrescenta-se a essa afirmação dois fatos primordiais: primeiro, de que a convenção firmada pelo falido também é válida, mas inoponível à massa; e segundo, de que o administrador, com autorização judicial, está autorizado a celebrar o pacto arbitral.

Comprova-se, também, que o advento da falência não atrai nem suspende os procedimentos arbitrais em curso, mas qualifica-se essa afirmação com a condicionante de que a lei falimentar impõe determinadas condições para que o processo possa desenvolverse, como a substituição do falido pelo administrador judicial e a mitigação da confidencialidade — se existente — em algumas situações.

Por fim, confirma-se, ainda, a ideia de que a sentença arbitral, uma vez proferida, deve ser submetida à processo de verificação no processo falimentar.

Respeitadas essas condições, conclui-se, inversamente, que nem a celebração da convenção de arbitragem, nem o desenvolvimento do procedimento arbitral, nem mesmo a prolação da sentença, viola a par conditio creditorium, objetivo máximo do sistema falimentar. 
Não há, pois, nenhuma incompatibilidade conceitual entre a falência e a arbitragem, que, nas condições estabelecidas nesta tese, podem pacificamente coexistir.

\section{Proposições objetivas}

Por fim, considerando que se discute atualmente a modificação da legislação falimentar, propõe-se, ao final desta tese, a introdução de três proposições na LREF, com a finalidade de pacificar a discussão sobre a possibilidade de coexistência entre a arbitragem e a falência.

\section{Proposicão n. 1}

As convenções de arbitragem firmadas pelo falido anteriormente à quebra permanecem válidas e eficazes no curso da falência. $\mathrm{O}$ administrador pode, mediante autorização judicial, firmar convenção de arbitragem versando sobre os bens e direitos submetidos ao concurso. A convenção de arbitragem não se submete à regra do art. 117 da LREF.

\section{Proposicão n. 2}

Os procedimentos arbitrais iniciados antes e depois do decreto de falência não são atraídos para o juízo falimentar. O administrador judicial deve substituir o falido em todos os procedimentos arbitrais, sob pena de nulidade. O falido poderá intervir como assistente em todos os procedimentos arbitrais. São inarbitráveis as causas expressamente reguladas na LREF, que tramitarão exclusivamente no juízo da falência.

Os procedimentos arbitrais iniciados antes e depois do decreto de falência não são suspensos pelo decreto falimentar. O árbitro tem competência para decidir sobre pedido de reserva de valores na falência, mas o juízo falimentar pode recusar o cumprimento da ordem em caso de existirem vícios formais, violação à ordem pública ou qualquer dos vícios prescritos no art. 32 da LARB.

Os procedimentos arbitrais, em sendo a confidencialidade comprovada perante o juízo falimentar, poderão manter-se confidenciais no curso da falência, mas o falido e o administrador judicial têm o dever de informar ao juízo falimentar sobre a existência do 
processo e prestar as informações solicitadas pelo juízo falimentar. A sentença arbitral deverá tornar-se conhecida de todos os participantes do processo falimentar.

\section{Proposicão n. 3}

Os créditos representados por sentença arbitral deverão ser submetidos ao processo de verificação de créditos no processo falimentar, e poderão ser impugnados nos termos do art. $8^{\circ}$ da LREF. A impugnação falimentar poderá versar sobre as causas de impugnação do art. $525, \S 1^{\circ}$, do CPC, bem como sobre as causas de nulidade previstas no art. 32 da LARB.

$* * * * * * * * * *$

Espera-se, com esta tese, ter contribuído para lançar alguma luz sobre a complexa relação entre a falência e a arbitragem. Buscou-se desfazer alguns equívocos interpretativos doutrinários e jurisprudenciais, bem como apresentar respostas para outros pontos que ainda não haviam sido suficientemente elucidados. Ao analisar os efeitos que a falência opera sobre a arbitragem, e demonstrar em que condições os dois institutos podem conviver, pretende-se, ainda que de forma singela, colaborar para o desenvolvimento da ciência jurídica, bem como para o aumento da segurança jurídica e da previsibilidade no mundo empresarial. 


\section{REFERÊNCIAS}

ABRÃO, Carlos Henrique. Comentários ao art. 70 ao 104. In: TOLEDO, Paulo F. C. Salles; ABRÃO, Carlos Henrique (coord.). Comentários à lei de recuperação de empresas e falência. 3. ed. rev. e atual. São Paulo: Saraiva, 2009, p. 209-335.

ABRÃO, Nelson. A continuação do negócio na falência. 2. ed. rev., amp. e atual. São Paulo: Universitária de Direito, 1998.

ABRÃO, Nelson. Os credores na falência. 2. ed. rev., amp. e atual. São Paulo: Universitária de Direito, 1998.

ABREU, José. O negócio jurídico e sua teoria geral. São Paulo: Saraiva, 1984.

ALMEIDA, José Gabriel Lopes Pires Assis de; RAMALHO, Matheus Sousa. A compatibilidade da Arbitragem com a falência e a recuperação judicial. In: CONGRESSO NACIONAL DO CONPEDI, 24.: "Direito Privado, Formas de Resolução de Controvérsias e Direitos Fundamentais" Belo Horizonte, UFMG/FUMEC/Dom Helder Câmara, 2015, p. 117-144.

ALVARES, Walter T. Direito falimentar: v. 1. 2. ed. rev. atual. São Paulo: Sugestões Literária, 1968.

ALVARES, Walter T. Direito falimentar: v. 2. 2. ed. rev. atual. São Paulo: Sugestões Literárias, 1968.

ALVES, Rafael Francisco. A inadmissibilidade das medidas antiarbitragem no Direito brasileiro. São Paulo: Atlas, 2009.

ALVES, Rafael Francisco; VERONESE, Ligia Espolaor. Arbitragem e empresas em crise: o acesso à Justiça e o cumprimento da convenção de arbitragem em vista da incapacidade financeira de uma das partes. Revista do Advogado, v. 36, n. 131, p. 176-187, out. 2016.

ALVIM, Thereza. O direito processual de estar em juízo. São Paulo: Revista dos Tribunais, 1996.

AMARAL SANTOS, Moacyr. Primeiras linhas de direito processual civil: v. 1. 20. ed. rev. e atual. São Paulo: Saraiva, 1998.

AMARAL SANTOS, Moacyr. Primeiras linhas de direito processual civil: v. 2. 19. ed. rev. e atual. São Paulo: Saraiva, 1999.

AMARAL SANTOS, Moacyr. Primeiras linhas de direito processual civil: v. 3. 17. ed. rev. e atual. São Paulo: Saraiva, 1999.

AMBROSINI, Stefano; CAVALLI, Gino; JORIO, Alberto. Il fallimento. In: COTTINO, Gastone (coord.). Trattato di Diritto Commerciale: v. 11, t. 2. Pádova: CEDAM, 2009. 
AMORIM FILHO, Agnelo. Critério científico para distinguir a prescrição da decadência e para identificar as ações imprescritíveis. Revista de Direito Processual Civil, v. 3, p. 95132, jan./jun. 1961.

ANCEL, Bertrand. O controle de validade da convenção de arbitragem: o efeito negativo da "competência- competência. Revista Brasileira de Arbitragem, v. 2, n. 6, p. 52-64, 2005.

ANCEL, Pascal, Arbitrage et procedures collectives. Revue de l'Arbitrage, v. 1983, p. 255279.

ANCEL, Pascal. Note: Cour de cassation (Ch. com.) 19 mai 1987. Revue de l'Arbitrage, v. 1988, n. 1, p. 142-148, 1988.

APRIGLIANO, Ricardo de Carvalho. Alocação de custas e despesas e a condenação em honorários advocatícios sucumbenciais em arbitragem. In: CARMONA, Carlos Alberto; LEMES, Selma M. Ferreira; MARTINS, Pedro A. Batista (coord.). 20 anos da Lei de Arbitragem: homenagem a Petrônio R. Muniz. Rio de Janeiro: Atlas, 2017, p. 649-671.

APRIGLIANO, Ricardo de Carvalho. Cláusula compromissória: aspectos contratuais. Revista do Advogado, v. 30, n. 116, jul. 2012.

AQUINO, Diva Carvalho de. Dos efeitos da decretação da falência em relação aos bens e pessoas do devedor e administradores. In: PAIVA, Luiz Fernando Valente de (coord.). Direito falimentar e a nova lei de falências e recuperação de empresas. São Paulo: Quartier Latin, 2005, p. 383-414.

ARMELIN, Donaldo. A arbitragem, a falência e a liquidação extrajudicial. Revista de Arbitragem e Mediação, v. 4, n. 13, abr./jun. 2007.

ARMELIN, Donaldo. Notas sobre a ação rescisória em matéria arbitral. Revista de Mediação e Arbitragem, v. 1, p. 11-20, jan./abr. 2004.

ASCARELLI, Túlio. Problemas das sociedades anônimas e Direito comparado. São Paulo: Quorum, 2008.

AZEVEDO, Álvaro Villaça. Teoria geral das obrigações e responsabilidade civil. 12. ed.. São Paulo: Atlas, 2011.

AZEVEDO, Antonio Junqueira de. Considerações sobre a boa-fé objetiva em acordos de acionistas com cláusula de preferência: excertos teóricos de dois pareceres. In: AZEVEDO, Antonio Junqueira de. Novos estudos e pareceres de Direito Privado. São Paulo: Saraiva, 2009.

AZEVEDO, Antonio Junqueira de. Negócio jurídico: existência, validade e eficácia. 4. ed. atual. São Paulo: Saraiva, 2002. 
BACCAGLINI, Laura. Fallimento e arbitrato rituale: profili di interrelazione e autonomia tra i due procedimenti. Trento: Università degli Studi di Trento, 2018.

BADEL, Francoise. Faillite et Arbitrage International. ASA Bulletin. Kluwer Law International, v. 25. n. 1, p. 36/47, 2007.

BALBINO, Inês. A arbitrabilidade do Direito Falimentar. In: LEMES, Selma M. Ferreira; BALBINO, Inês (coord.). Arbitragem: temas contemporâneos. São Paulo: Quartier Latin, 2012, p. 199-219.

BAPTISTA, Luiz Olavo. Confidencialidade na arbitragem. In: CONGRESSO DO CENTRO DE ARBITRAGEM COMERCIAL, 5. Coimbra: Almedina, 2012.

BARBOSA MOREIRA, José Carlos. Invalidade e ineficácia do negócio jurídico. In: TEPEDINO, Gustavo; FACHIN, Luiz Edson (org.). Obrigações e contratos: obrigações: funções e eficácia. São Paulo: Revista dos Tribunais, 2011, v. 2, p. 639-654. [Coleção "Doutrinas Essenciais"].

BARDALES, Enrique Miguel Chávez. Privacidad y Confidencialidad en el Arbitraje Comercial Internacional. Disponível em: http://www.servilex.com.pe/arbitraje/colaboraciones/privacidad-arbitraje.html. Acesso em: 05 jan. 2020.

BASÍLIO, Ana Tereza; LINS, Thiago. A relativização da confidencialidade na arbitragem: companhias abertas. Revista de Arbitragem e Mediação, v. 49, p. 157-172, abr./jun. 2016.

BATALHA, Wilson de Souza Campos; BATALHA, Silvia Marina Labate. Falências e concordatas: comentários à lei de falências: doutrina, legislação, jurisprudência. São Paulo: LTr, 1991.

BENETI, Giovana. Arbitragem e empresas em crise: o problema da arbitrabilidade objetiva. Revista Jurídica Luso-Brasileira, v. 5, n. 1, p. 879-917, 2019.

BERNARDES DE MELLO, Marcos. Teoria do fato jurídico: plano da existência. 8. ed. atual. São Paulo: Saraiva, 1998.

BERNARDES DE MELLO, Marcos. Teoria do fato jurídico: plano da validade. 8. ed. rev. e atual. São Paulo: Saraiva, 2008.

BERSET, Dominique; LÉVY, Laurent. Faillite et arbitrage. ASA Bulletin. Kluwer Law International, v. 16, n. 4, p. 664-680, 1998.

BESSONE, Darcy. Do contrato: teoria geral. 4. ed. São Paulo: Saraiva, 1997.

BESSONE, Darcy. Instituições de Direito Falimentar. São Paulo: Saraiva, 1995. 
BETTI, Emilio. Teoria geral do negócio jurídico: t. 1. Tradução de Fernando de Miranda. Coimbra: Coimbra Editora, 1969.

BETTI, Emilio. Teoria geral do negócio jurídico: t. 2. Tradução de Fernando de Miranda. Coimbra: Coimbra Editora, 1969.

BEZERRA FILHO, Manoel Justino. Capítulo XVIII - Os efeitos da decretação da falência sobre as obrigações do devedor - Exame dos arts. 119 a 128 da Lei 11.101/2005. In: CARVAlHOSA, Modesto (coord.). Tratado de Direito Empresarial, v. 5: recuperação judicial e falência. São Paulo: Revista dos Tribunais, 2016.

BEZERRA FILHO. Manoel Justino. Lei recuperação de empresas e falência: Lei 11.101/2005: comentada artigo por artigo. 9. ed, rev. atual. e ampl. São Paulo: Revista dos Tribunais, 2013.

BOCCARDO, Victor Cogliati. Arbitragm e deveres de informação no mercado de capitais. 30 jan. 2007. Disponível em: http://cbar.org.br/site/arbitragem-e-deveres-deinformacao-no-mercado-de-capitais. Acesso em: 05 dez. 2019.

BONELLI, Gustavo. Del fallimento: v. 1. Milano: Dotto Francesco Vallardi, 1938.

BONELLI, Gustavo. Del fallimento: v. 2. Milano: Dotto Francesco Vallardi, 1938.

BONELLI, Gustavo. Del fallimento: v. 3. Milano: Dotto Francesco Vallardi, 1938.

BORN, Gary B. International Commercial Arbitration: v. 1. Netherlands: Kluwer International Law, 2009.

BORN, Gary B. International Commercial Arbitration: v. 2. Netherlands: Kluwer International Law, 2009.

BOSCO LEE, João.O princípio da confidencialidade na arbitragem comercial internacional. In: VALENÇA FILHO, Clávio de Melo; BOSCO LEE, João. Estudos de arbitragem. Curitiba: Juruá, 2008.

BOVE, Mauro. Arbitrato e Fallimento. 2012. Disponível em: http://www.judicium.it/arbitrato-e-fallimento. Acesso em: 08 dez. 2019.

BRAGHETTA, Adriana. Notas sobres confidencialidade na arbitragem. Revista do Advogado, v. 33, n. 119, p. 7-13, abr. 2013.

CABRAL, Thiago Dias Delfino Cabral. A mitigação da confidencialidade da arbitragem na recuperação judicial. Revista Brasileira de Arbitragem, v. 15, n. 57, p. 45-66, 2018. 
CABRAL, Thiago Dias Delfino. A impecuniosidade na arbitragem: um grave problema na instauração do procedimento arbitral, um novo conceito e uma proposta de solução à luz do princípio do acesso à justiça. Dissertação (Mestrado) - Faculdade de Direito, Universidade do Estado do Rio de Janeiro. Rio de Janeiro, 2019.

CABRAL, Thiago Dias Delfino. A mitigação da confidencialidade da arbitragem na recuperação judicial. Revista Brasileira de Arbitragem. Kluwer Law International, v. 15, n. 57, p. 45-66, 2018.

CAHALI, Francisco José. Curso de arbitragem: mediação, conciliação, tribunal multiportas. São Paulo: Revista dos Tribunais, 2015.

CAHALI, Yussef Said. Honorários advocatícios. 3. ed. rev., atual. e ampl. São Paulo: Revista dos Tribunais, 1997.

CÂMARA, Alexandre Freitas. Arbitragem: Lei n. 9.307/96. 3. ed. rev. amp. atual. Rio de Janeiro. Lumen Iures, 2002.

CAMPINHO, Sérgio. Curso de Direito Comercial: falência e recuperação de empresa, 2018.

CAMPINHO, Sérgio. Falência e recuperação de empresa: o novo regime da insolvência empresarial. 6. ed. Rio de Janeiro: Renovar, 2012.

CANALE, Guido. Capitolo XV: Clausola arbitrale. In: CAGNASSO, Oreste; PANZANI, Luciano. Crisi di impresa e procedure concorsuali: t. 1. UTET, 2016, p. 1.563-1.590.

CANALE, Guido. Clausola Arbitrale in Crisi di impresa e procedure concorsuali diretto da Oreste Cagnasso e Luciano Panzani, Vol. I, UTET, p. 1568, 2016

CAPPELlETTI, Mauro; GRATH, Brant. Acesso à Justiça. Tradução de Ellen Gracie Northfleet. Porto Alegre: Fabris, 1988.

CARAMELO, António Sampaio. A "autonomia" da cláusula compromissória e a competência da competência do Tribunal Arbitral. In: Homenagem da Faculdade de Direito de Lisboa ao Professor Doutor Inocêncio Galvão Telles, 90 Anos. Coimbra: Almedina, 2007, p. 105-128.

CARAMELO, António Sampaio. Critérios da arbitrabilidade dos litígios: revisitando o tema. Revista de Mediação e Arbitragem, v. 7, v. 27, p. 129-161, out./dez. 2010.

CARMONA, Carlos Alberto. Arbitragem e administração pública: primeiras reflexões sobre a arbitragem envolvendo a administração pública. Revista Brasileira de Arbitragem. Kluwer Law International, v. 8, n. 51, p. 7-21, 2016. 
CARMONA, Carlos Alberto. Arbitragem e processo: um comentário à Lei n. 9.307/96. 3. ed. rev., atual. e ampl. São Paulo: Atlas, 2009.

CARNELUTTI, Francesco. Instituições de processo civil: v. 1. Tradução de Adrián Sotero de Witt Batista. Campinas, SP: Servanda, 1999.

CARNELUTTI, Francesco. Instituições de processo civil: v. 2. Tradução de Adrián Sotero de Witt Batista. Campinas, SP: Servanda, 1999.

CARNELUTTI, Francesco. Instituições de processo civil: v. 3. Tradução de Adrián Sotero de Witt Batista. Campinas, SP: Servanda, 1999.

CARREIRA ALVIM, J. E. Comentários à Lei de Arbitragem: Lei n. 9.307, de 23/9/1996. Rio de Janeiro: Lumen Juris, 2002.

CARREIRA ALVIM, J. E. Direito arbitral. Rio de Janeiro: Forense, 2004.

CARREIRA ALVIM, J. E. Tutela específica das obrigações de fazer, não fazer e entregar coisa. 3. ed. Rio de Janeiro: Forense, 2003.

CARRETEIRO, Matheus A. Tutelas de urgência e processo arbitral. Dissertação (Mestrado) - Faculdade de Direito, Universidade de São Paulo. São Paulo, 2013.

CARVALHO DE MENDONÇA, J. X. Tratado de Direito Comercial brasileiro: v. 7. Rio de Janeiro: Freitas Bastos, 1946.

CARVALHO DE MENDONÇA, J. X. Tratado de Direito Comercial brasileiro: v. 8. Rio de Janeiro: Freitas Bastos, 1947.

CARVALHO SANTOS, João Manuel de. Código civil brasileiro interpretado: principalmente do ponto de vista prático: v. 15. 12. ed. Rio de Janeiro: Freitas Bastos, 1989.

CASADO FILHO, Napoleão. Arbitragem comercial internacional e acesso à justiça: o novo paradigma do third party funding. Tese (Doutorado) - Faculdade de Direito, Pontifícia Universidade Católica de São Paulo, São Paulo, 2014.

CASTAGNOLA, Angelo. Procedimento arbitral, lodo e fallimento. Rivista Trimestrale di Diritto e Procedura Civile, n. 3, p. 821-835, 2016.

CASTRO NEVES, José Roberto. Os honorários advocatícios de sucumbência na arbitragem. In: CARMONA, Carlos Alberto; LEMES, Selma M. Ferreira; MARTINS, Pedro A. Batista (coord.). 20 anos da Lei de Arbitragem: homenagem a Petrônio R. Muniz. Rio de Janeiro: Atlas, 2017, p. 622-632.

CENSONI, Paolo Felice. Effetti sui rapporti giuridici preesistenti. In: DIDONE, Antonio. Le riforme della legge fallimentare. UTET, 2009, p. 769-817. 
CHÁVEZ BARDALES, Enrique Miguel. Privacidad y Confidencialidad en el Arbitraje Comercial Internacional. Disponível em: www.servilex.com.pe/arbitraje/colaboraciones/privacidad-arbitraje.html. Acesso em: 05 dez. 2019.

CHIN, Andrew. What Can Happen if Parties Fail to Pay the Advance on Costs Requested by the ICC. Global Arbitration News, 21 abr. 2015. Disponível em: https://globalarbitrationnews.com/failing-to-pay-the-advance-on-costs-requested-by-the-icc-20150420. Acesso em : 11 out. 2019.

CHIOVENDA, Giuseppe. Instituições de direito processual civil: v. 1. Campinas, SP: Bookseller, 1998.

CHIOVENDA, Giuseppe. Instituições de direito processual civil: v. 2. Campinas, SP: Bookseller, 1998.

CHIOVENDA, Giuseppe. Instituições de direito processual civil: v. 3. Campinas, SP: Bookseller, 1998.

COELHO, Fabio Ulhoa. Comentários à nova lei de falências e recuperação de empresas: Lei n. 11.101, de 9-2-2005. 4. ed.. São Paulo: Saraiva, 2007.

COELHO, Fábio Ulhoa. Parecer para cervejaria Petrópolis. Disponível em: https://www.conjur.com.br/dl/parecer-cervejaria-petropolis-bva.pdf. 2015. Acesso em: 23 ago. 2019.

COMPARATO, Fábio Konder; SALOMÃO FILHO, Calixto. O poder de controle na sociedade anônima. 6. ed. rev. e atual. Rio de Janeiro: Forense, 2014.

CORREA, Raphael Nehin. Arbitragem e Insolvência. In: PEREIRA LIMA, Flávio; MIRANDA, Daniel Calhman de; et al. . Arbitragem no Brasil. São Paulo: Impressão Régia, 2010.

COSSÍO, Francisco González de. El princípio competénce-competénce revisitado. Revista de Mediação e Arbitragem, v. 4, n. 13, p. 100/122, abr./jun. 2007.

COUTURE, Eduardo J. Fundamentos del derecho procesal civil. Buenos Aires: Depalma, 1993.

CREMASCO, Suzana Santi. O artigo 485, VII, do Novo Código de Processo Civil e o reconhecimento de competência pelo árbitro como pressuposto processual negativo no processo judicial. Revista Brasileira de Arbitragem. Kluwer Law International, v. 14, n. 53, p. 7-24, 2017.

CRETELLA NETO, José. Curso de Arbitragem: arbitragem comercial, arbitragem internacional, lei brasileira de arbitragem, instituições internacionais de arbitragem, Convenções internacionais sobre arbitragem. Rio de Janeiro: Forense, 2004. 
CRETELLA NETO, José. Quão sigilosa é a arbitragem? Revista de Arbitragem e Mediação, n. 25, p. 44-70, 2010.

CRIPPA, Carla de Vasconcelos. Recuperação Judicial, falência e arbitragem. Revista de Arbitragem e Mediação, v. 8, n. 29, p. 183-206, abr./jun. 2011.

CRUZ E TUCCI, Jose Rogério. Tempo e processo: uma análise empírica das repercussões do tempo na fenomenologia processual (civil e penal). São Paulo: Revista dos Tribunais, 1997.

D’AVACK, Carlo. La natura giuridica del falimento. Pádua: CEDAM, 1940.

DANTAS, San Tiago. Programa de Direito Civil: v. 1. Rio de Janeiro: Rio Sociedade Cultural, 1979.

DE LUCCA, Newton. Comentários aos artigos $1^{\circ}$ ao $6^{\circ}$. In: DE LUCCA, Newton; SIMÃO FILHO, Adalberto (coord.). Comentários à Nova Lei de Recuperação de Empresas e de Falências. São Paulo: Quartier Latin, 2005, p. 71-126.

DE PLÁCIDO E SILVA. Vocabulário jurídico. Atualização de Nagib Slaibi Filho e Priscila Pereira Vasques Gomes. 32. ed. Rio de Janeiro: Forense, 2016.

DEBOURG, Claire; SILVEIRA, Gustavo Scheffer da. Note: Jutaí 661 Equipamentos Eletrônicos Ltda. v. PSI Comércio e Prestação de Serviços em Telefones Celulares Ltda., Superior Tribunal de Justiça do Brasil, Recurso Especial no 1.277.725 - AM (2011/01469222), 12 March 2013. Revue de l’Arbitrage, v. 2014, n. 3, p. 735-737, 2014.

DECCACHE, Antonio Carlos Fernandes. Cláusula de Arbitragem nos Contratos Comerciais Internacionais. São Paulo: Altas, 2015.

DECCACHE, Antonio Carlos Fernandes. Convenção de arbitragem, recuperação judicial e falência. Revista de Direito Empresarial, v. 19, p. 163-182, out. 2016.

DELGADO, José Augusto. Comentários ao novo Código Civil. v. 11, t. 2. Rio de Janeiro, Forense: 2004.

DERAINS, Bertrand. Carrefour v. Le Castel AS, Cour de Cassation, Case No. 10-18320, 28 September 2011. A contribution by the ITA Board of Reporters. The Hague: Kluwer Law International, 2011.

DERAINS, Yves; KIFFER, Laurence. National Report for France (2013 through 2018). In: BOSMAN, Lise. (ed.). ICCA International Handbook on Commercial Arbitration. ICCA \& Kluwer Law International, Supplement n. 99, 2018, p. 1-98.

DINAMARCO, Cândido Rangel. A arbitragem na teoria geral do processo. São Paulo: Malheiros, 2013. 
DINAMARCO, Cândido Rangel. Execução civil. 7. ed. rev. atual. São Paulo: Malheiros Editores, 2000.

DINAMARCO, Candido Rangel. Fundamentos do processo civil moderno. t. 1. 3. ed. rev. atual. São Paulo: Malheiros. 2000.

ENNECERUS, Ludwig; KIPP, Theodor; WOLF, Martin. Tratado de Derecho Civil: v. 1. 2. ed. Barcelona: Bosch, 1953.

FARIA, Antonio Bento de. Das fallencias. 2. ed. Rio de Janeiro: Jacinto Ribeiro dos Santos, 1903.

FARIA, Luis Cláudio Furtado; COZER, Felipe Rodrigues. A arbitragem e a recuperação judicial em um estudo sobre a conveniência e possíveis conflitos entre os institutos. Revista de Arbitragem e Mediação. São Paulo: RT, v 7, n. 31, p. 251-261, out./dez. 2011.

FARIA, Luis Cláudio Furtado; COZER, Felipe Rodrigues. A arbitragem e a recuperação judicial em um estudo sobre a conveniência e possíveis conflitos entre os institutos. Revista de Arbitragem e Mediação, São Paulo: RT, ano 7, v. 31, p. 251-261, out.-dez. 2011

FAZZIO JÚNIOR, Waldo. Manual de Direito Comercial. 20. ed. São Paulo: Atlas, 2019.

FERRARA JUNIOR, Francesco; BORGIOLI, Alessandro. Il Fallimento. 5. ed. Milano: Giuffré, 1995.

FERRARA, Francesco. Il Fallimento. 3. ed. Milano: Giuffrè, 1974.

FERREIRA, Waldemar. Instituições de Direito Comercial: v. 4. Freitas Bastos, 1946.

FERREIRA, Waldemar. Tratado de Direito Comercial: v. 14. São Paulo: Saraiva, 1965.

FERREIRA, Waldemar. Tratado de Direito Comercial: v. 15. São Paulo: Saraiva, 1965.

FIGUEIRA JUNIOR, Joel Dias. Arbitragem. 3. ed. Rio de Janeiro: Forense, 2019.

FITCHNER, José Antonio; MANNHEIMER, Sergio Nelson; MONTEIRO, André Luís. A confidencialidade na arbitragem: regra geral e exceções. Revista de Direito Privado, n. 49, 2012, p. 227-285.

FITCHNER, José Antonio; MANNHEIMER, Sergio Nelson; MONTEIRO, André Luís. Teoria geral da arbitragem. Rio de Janeiro: Forense, 2019.

FONSECA, Rodrigo Garcia da; CORREIA, André de Luizi. A confidencialidade na arbitragem. Fundamentos e limites. In: LEMES, Selma M. Ferreira; BALBINO, Inês. Arbitragem: temas contemporâneos. São Paulo: Quartier Latin, 2012, p. 416-448. 
FONTES, Marcos Rolim Fernandes. A arbitragem e a decretação da falência no curso do procedimento arbitral. Revista do Instituto dos Advogados de São Paulo, v. 23, p. 297311, jan./jun. 2009.

FOUCHARD, Philippe. Arbitrage et faillite. Revue de l'Arbitrage, v. 1998, n. 3, p. 471494, 1998.

FOUCHARD, Philippe; GAILLARD, Emmanuel; GOLDMAN, Berthold. International Commercial Arbitration. The Hague: Kluwer Law International, 1999.

FRONTINI, Paulo Salvador. Comentários aos arts. 115-128. In: SOUZA JUNIOR, Francisco Satiro; PITOMBO, Antonio Sérgio A. e Moraes (coord.). Comentários à lei de recuperação de empresas e falência: Lei 11.101/2005. São Paulo: Revista dos Tribunais, 2007, p. 434-468.

GABARDO, Rodrigo Araújo. A insuficiência de recursos financeiros na instauração da arbitragem comercial: efeitos no direito brasileiro a partir de uma perspectiva comparada. Dissertação (Mestrado) - Faculdade de Direito, Universidade de São Paulo. São Paulo, 2014.

GAGLIARDI, Rafael Villar. Confidencialidade na arbitragem comercial internacional. Revista de Arbitragem e Mediação, n. 36, p. 95-135, 2013.

GAILLARD, Emmanuel. O efeito negativo da competência-competência. Revista Brasileira de Arbitragem, v. 6, n. 24, p. 219-233, 2009.

GAJARDONI, Fernando da Fonseca. Aspectos fundamentais de processo arbitral e pontos de contato com a jurisdição estatal. Revista de Processo, v. 106, p. 189-216, abr./jun. 2002.

GALVÃo TELLES, Inocêncio. Manuel dos Contratos em Geral. 3. ed. Lisboa: Coimbra Editora, 1965.

GASIOROWSKI, Kuba; KOS, Rafal. Elektrim case comes to an end, 23 jul. 2015. Disponível em: https://www.internationallawoffice.com/Newsletters/ArbitrationADR/Poland/Kubas-Kos-Gakowski/Elektrim-case-era-comes-to-an-end?redir=1. Acesso em: 25 nov. 2019.

GENOVIVA, Pietro. Gli effetti patrimoniali e personali del fallimento per il fallito. In: FAUCEGLIA, G.; PANZANI, L... Fallimento e altre procedure concorsuali, v. 1. UTET, 2009, p. 443-477.

GOMES, Orlando. Introdução ao Direito Civil. 12. ed. Rio de Janeiro: Forense, 1996.

GOMES, Orlando. Introdução ao Direito Civil. 19. ed. rev., atual e aum. de acordo com o Código Civil de 2002. Rio de Janeiro: Forense, 2008. 
GONÇALVES, Eduardo Damião. Arbitrabilidade objetiva. Tese (Doutorado) - Faculdade de Direito, Universidade de São Paulo. São Paulo, 2008.

GRAZIANI, Carlo Alberto; MINERVINI, Gustavo; BELVISO, Umberto; SANTORO, Vittorio. Manuale di Diritto Commerciale. 15. ed. Pádova: CEDAM, 2013, p. 777-783.

GRION, Renato Stephan; PAIVA, Luiz Fernando Valente de; ANDRADE SILVA, Guilherme Piccardi de. A arbitragem no contexto das recuperações judiciais e extrajudiciais e das falências. In: CAMPOS MELO, Leonardo de; BENEDUZI, Renato Rezende. A reforma da arbitragem. Rio de Janeiro: Forense, 2016, p. 83-114.

GUERREIRO, Luis Fernando. Convenção de arbitragem e processo arbitral. Rio de Janeiro: Atlas, 2014.

GUERREIRO, Luis Fernando. Cumprimento da sentença arbitral e a Lei 11.232/2005. Revista de Mediação e Arbitragem, v. 15, p. 102-116, out./dez. 2007.

GUGLIELMUCCI, Lino. Gli effetti del fallimento per il fallito. In: VASSALLI, Francesco; LUISO, Francesco P.; GABRIELLI Enrico. Trattato di Diritto Fallimentare e Delle Altre Procedure Concursuali, v. 3: Gli effetti del fallimento, Torino: Giappichelli, 2014, p. 1-48.

HANOTIAU, Bernard; SHCWARTZ, Eric. Multiparty Arbitration. International Chamber of Commerce - ICC, 2010.

HENTZ, Luiz Antonio Soares. Comentários aos artigos 115 ao 128. In: DE LUCCA, Newton; e SIMÃO FILHO, Adalberto (coord.). Comentários à Nova Lei de Recuperação de Empresas e de Falências. São Paulo: Quartier Latin, 2005.

JACKSON, Thomas. The Logic and Limits of Bankruptcy Law. Cambridge, Mas.: Harvard University, 1986.

JARROSSON, Charles. Reflexões sobre o imperium. Revista brasileira de arbitragem. São Paulo: Sïntese, v. 7, n. 27, jul./set, p. 203-231, 2010.

JUDICE, José Miguel. Anotação ao acórdão Esso Australia Resources Limited and Others v. The Honourable Sidney Jamos Plowman and Others. In: 100 Anos de Arbitragem: os casos essenciais comentados. Coimbra: Coimbra Editora, 2016. [Coleção "PLMJ", n. 9, p. 153-164].

KARRER, Pierre A. Views on the Decision by the Swiss Supreme Court: Note: 31 March 2009: Swiss Supreme Court. ASA Bulletin. Association Suisse de l'Arbitrage; Kluwer Law International, v. 28, n. 1, p. 111-112, 2010.

KIRGIS, Paul. Arbitration, Bankruptcy and Public Policy: A Contractarian Analysis. American Bankruptcy Institute Law Review, v. 17, n. 2, p. 503-549, 2009. 
KUHNER, Detlev. The Impact of Party Impecuniosity on Arbitration Agreements: The Example of France and Germany. Journal of International Arbitration. Kluwer Law International; Kluwer Law International, v. 31, n. 6, p. 807-818, 2014.

LACERDA, Paulo Maria de. Da Fallencia no Direito brasileiro. São Paulo: Editora Nacional, 1931.

LARENZ, Karl. Derecho Civil: parte general. Tradução de Miguel Izquierdo y MacíasPicavea. Jaén: Revista de Derecho Privado, 1978.

LAZIC, Vezna. Insolvency Proceedings and Commercial Arbitration. The Hague: Kluwer Law International, 1998.

LEITÃO, Luís Manuel Teles de Menezes. Os efeitos da insolvência sobre os processos de arbitragem internacional. Revista de Arbitragem e Mediação, v. 43, p. 297-305, out./dez. 2014.

LEMBO, Saverio; GUIGNET, Vicent. Confidentiality in Arbitration: From Myth to Reality. In: FALL MEETING. Montreal: American Bar Association, International Section, set. 2015.

LEMES, Selma M. Ferreira. Arbitragem em números e valores: Pesquisa de Arbitragem em Número e Valores: 2010-2017. 2018. Disponível em: http://selmalemes.adv.br/publicacoes.asp?linguagem=Portugu\%EAs\&secao=Publica\%E7 $\% \mathrm{~F} 5$ es\&subsecao $=\mathrm{T} \% \mathrm{~F} 3$ picos $\&$ acao $=$ Consulta\&especificacao $=$ Artigos. Acesso em: 05 jan. 2020.

LEMES, Selma M. Ferreira. Arbitragem na Administração Pública: fundamentos jurídicos e eficiência econômica. São Paulo: Quartier Latin, 2007.

LEMES, Selma M. Ferreira. Arbitragem na concessão de serviços públicos: arbitrabilidade objetiva: confidencialidade ou publicidade processual? Palestra proferida na reunião do Comitê Brasileiro de Arbitragem - CBAR realizada em São Paulo, em 06.05.2003. RDM, n. 134, p. 148-163, abr./jun. 2004.

LEMES, Selma M. Ferreira. Árbitro: princípios da independência e da imparcialidade: abordagem no direito internacional, nacional e comparado: jurisprudência (Lei n. 9.307/96, sobre arbitragem). São Paulo: LTr, 2001.

LEMES, Selma M. Ferreira. Os princípios jurídicos da lei de arbitragem. In: MARTINS, Pedro A. Batista; LEMES, Selma M. Ferreira; CARMONA, Carlos Alberto. Aspectos fundamentais da lei de arbitragem. Rio de Janeiro: Forense, 1999, p. 73-112.

LEW, Mathew et al. Comparative International Commercial Arbitration. The Hague: Kluwer Law International, 2003.

LIEBMAN, Enrico Tullio. Eficácia e autoridade da sentença. 3. ed. Tradução de Alfredo Buzaid. Rio de Janeiro: Forense, 1984. 
LIEBSCHER, Christoph. Insolvency and Arbitrability. In: MISTELIS, Loukas A.; BREKOULAKIS, Stravos (eds). Arbitrability: International and Comparative Perspectives. The Hague: Kluwer Law International; Kluwer Law International, 2009. International Arbitration Law Library, v. 19, cap. 9, p. 165-178.

LIMA, Bernardo. Decurso simultâneo de processo falimentar e procedimento arbitral. Revista de Direito Recuperacional e Empresa, v. 9, jul./set. 2018.

LY, Filip de; BROZOLO, Luca G. Radicati di; FRIEDMAN, Mark. Confidentiality in International Commercial Arbitration. Revista de Arbitragem e Mediação, v. 31, p. 191246, 2011.

MAGAlHÃES, Rodrigo Almeida. Arbitragem e Convenção Arbitral. Belo Horizonte: Mandamentos, 2006.

MANGE, Flavia Foz. Processo arbitral: aspectos transnacionais. São Paulo: Quartier Latin, 2013.

MANTILLA-SERRANO, Fernando. International Arbitration and Insolvency Proceedings. Arbitration International. Londres, v. 11, n. 1, p. 51-74, 1995.

MARCATO, Antonio Carlos (coord.). Código de Processo Civil interpretado. 3. ed. São Paulo: Atlas, 2008.

MARCONDES, Sylvio. Questões de Direito Mercantil. São Paulo: Saraiva, 1977.

MARINONI, Luiz Guilherme; MITIDIERO, Daniel. Comentários ao Código de Processo Civil: artigos $1^{\circ}$ ao 69. In: MARINONI, Luiz Guilherme; MITIDIERO, Daniel; ARENHART, Sérgio Cruz (coord.). Comentários ao Código de Processo Civil: v. 1. São Paulo: Revista dos Tribunais, 2016.

MARQUES, José Frederico. Instituições de Direito Processual Civil: v. 1. Campinas, SP: Millennium, 2000.

MARQUES, José Frederico. Instituições de Direito Processual Civil: v. 2. Campinas, SP: Millennium, 2000.

MARQUES, José Frederico. Instituições de Direito Processual Civil: v. 3. Campinas, SP: Millennium, 2000.

MARQUES, José Frederico. Instituições de Direito Processual Civil: v. 4. Campinas, SP: Millennium, 2000.

MARQUES, José Frederico. Instituições de Direito Processual Civil: v. 5. Campinas, SP: Millennium, 2000. 
MARTINEZ, Ana Paula. Política de Divulgação de informações no âmbito do mercado de capitais. Revista de Direito Bancário e do Mercado de Capitais, v. 28, p. 95-109, abr./jun., 2005.

MARTINS, Pedro A. Batista. Anotações sobre a sentença proferida em sede arbitral. In: MARTINS, Pedro A. Batista; LEMES, Selma M. Ferreira; CARMONA, Carlos Alberto. Aspectos fundamentais da lei de arbitragem. Rio de Janeiro: Forense, 1999.

MARTINS, Pedro A. Batista. Apontamentos sobre a arbitragem no Brasil. Revista do Advogado. São Paulo, n. 51, out. 1997.

MARTINS, Pedro A. Batista. Apontamentos sobre a lei de arbitragem: comentários à lei 9.307/96. Rio de Janeiro: Forense, 2008.

MARTINS, Pedro A. Batista. Da ausência de poderes coercitivos e cautelares do árbitro. In: MARTINS, Pedro A. Batista; LEMES, Selma M. Ferreira; CARMONA, Carlos Alberto. Aspectos fundamentais da lei de arbitragem. Rio de Janeiro: Forense, 1999, p. 357-382.

MARTINS-COSTA, Judith. Comentários ao novo Código Civil: v. 5, t. 1: do direito das obrigações, do adimplemento e da extinção das obrigações. Rio de Janeiro: Forense, 2003.

MATTOS NETO, Antônio José de. Direitos patrimoniais disponíveis e indisponíveis à luz da lei de arbitragem. Revista de Processo, v. 106, p. 221-236, abr./jun. 2002.

MAZZONETTO, Nathália. Arbitragem e propriedade intelectual: aspectos estratégicos e polêmicos. São Paulo: Saraiva, 2017.

MELLO FRANCO, Vera Helena de. Comentários ao art. 103. In: SOUZA JUNIOR, Francisco Satiro de (coord.); PITOMBO, Antônio Sérgio A. De Moraes (coord.). Comentários à Lei de recuperação de empresas e falência: Lei 11.101/2005: artigo por artigo. São Paulo: Revista dos Tribunais, 2007, p. 419-421.

MELlO FRANCO, Vera Helena de. Contratos: Direito Civil e Empresarial. 2. ed. São Paulo: Revista dos Tribunais, 2011.

MELLO FRANCO, Vera Helena de; SZTAJN, Rachel. Falência e recuperação da empresa em crise. Rio de Janeiro: Elsevier, 2008.

MELLO FRANCO, Vera Helena; SZTAJN, Rachel. Falência e recuperação da empresa em crise: comparação com as posições do direito europeu. Rio de Janeiro: Elsevier, 2008.

MELO, Leonardo de Campos. Extensão da cláusula compromissória e grupos de sociedades: a prática arbitral CCI e sua compatibilidade com o direito brasileiro. Rio de Janeiro: Forense, 2013. 
MENDES, Gilmar Ferreira; BRANCO, Paulo Gustavo Gonet. Curso de Direito Constitucional. 14. ed. rev. e atual. São Paulo: Saraiva Educação, 2019.

MENDES, Octávio. Fallencias e concordatas: de acordo com o Decreto n. 5.746, de 9 de dezembro de 1929. São Paluo: Saraiva, 1930.

MENDES, Rodrigo Octávio Broglia. Arbitragem: lex mercatória e Direito estatal. Rio de Janeiro: Quartier Latin, 2010.

MERCEREAU, Ana Gerdau de Borja. Note: Société Aéronautique et technologies embarqués (ATE) v. Companies Airbu helicopters and Airbus Helicopters Deutschland, Court of Cassation of France, First Civil Law Chamber, Case No. 15-19389, 13 July 2016. Revista Brasileira de Arbitragem. Kluwer Law International, v. 14, n. 55, p. 149-155, 2017.

MESSINEO, Francesco. Doctrina general del contrato: t. 1. Tradução de R. O. Fontanarrosa, S. Sentis Melendo e M. Volterra. Buenos Aires: Ediciones Juridicas EuropaAmerica, 1986.

MESSINEO, Francesco. Manual de Derecho Civil y Comercial: t. 2. Tradução de Santiago Sentis Melendo. Buenos Aires: Ediciones Juridicas Europa-America, 1954.

MIRANDA VALVERDE, Trajano de. Comentários à Lei de Falências: v. 1. 4. ed. rev. atual. São Paulo: Forense, 1999.

MIRANDA VALVERDE, Trajano de. Comentários à Lei de Falências: v. 2. 4. ed. rev. atual. São Paulo: Forense, 1999.

MIRANDA VALVERDE, Trajano de. Comentários à Lei de Falências: v. 3. 4. ed. rev. atual. São Paulo: Forense, 1999.

MONTEIRO, Andre Luis. The Kompetenz-Kompetenz Rule in Brazilian Arbitration Law. Kluwer Arbitration Blog, 29 maio 2019. Disponível em: http://arbitrationblog.kluwerarbitration.com/2019/05/29/the-kompetenz-kompetenz-rulein-brazilian-arbitration-law. Acesso em: 03 dez. 2019.

MONTEIRO, Washington de Barros. Curso de Direito Civil: v. 1: parte geral. 34. ed. São Paulo: Saraiva, 1996.

MORAES, Felipe Ferreira Machado. A utilização da arbitragem por empresas em falência. Dissertação (Mestrado) - Pontifícia Universidade Católica de Minas Gerais. Belo Horizonte, 2014.

MORAES, Felipe Ferreira Machado. Arbitragem e falência. In: CARMONA, Carlos Alberto; LEMES, Selma M. Ferreira; MARTINS, Pedro A. Batista (coord.). 20 anos da Lei de Arbitragem: homenagem a Petrônio R. Muniz. Rio de Janeiro: Atlas, 2017, p. 741-771. 
MOREIRA, José Carlos Barbosa. O novo processo civil brasileiro: exposição sistemática do procedimento. 10. ed. rev. e atual. Rio de Janeiro: Forense, 1999.

MOTA PINTO, Carlos Alberto da. Teoria Geral do Direito Civil. 3. ed. atual. Coimbra: Coimbra Editora, 1994.

MOURRE, Alexis; VAGENHEIM, Alexandre. Some Comments on Denial of Justice in Public and Private International Law After Loewen and Saipem. In: FERNANDEZBALLESTER, Miguel Angel; LOZANO, David Arias (eds). Liber Amicorum Bernardo Cremades. Wolters Kluwer España; La Ley, 2010, p. 843-866.

MUNHOZ, Eduardo Secchi. Seção IV: Do procedimento de recuperação judicial. In: SOUZA JUNIOR, Francisco Satiro de; PITOMBO, Antônio Sérgio A. de Moraes (coord.). Comentários à Lei de Recuperação de Empresas e Falência: Lei 11.101/2005. 2. ed. São Paulo: RT, 2007, p. 270-319.

NAEGELI, Georg. Chapter III: The Award and the Courts: Bankruptcy and Arbitration: What Should Prevail? The Impact of Bankruptcy on Pending Arbitral Proceedings. Austrian Yearbook on International Arbitration, v. 2010, p. 193-207, 2010.

NANNI, Giovanni Ettore. Direito civil e arbitragem. São Paulo: Atlas, 2014.

NARDO, Giulio Nicola. Art. 72 Rapporti Pendenti. In: FERRO, Massimo. La legge fallimentare: commentario teorico-pratico. Torino: CEDAM, 2014, p. 968-980.

NASSER, Paulo Magalhães. Apontamentos sobre o desenvolvimento da arbitragem comercial e o controle de legalidade das sentenças arbitrais por meio de ação anulatória e impugnação ao cumprimento de sentença. In: CAHALI, Francisco José; RODOVALHO, Thiago; FREIRE, Alexandre (org.). Arbitragem: estudos sobre a Lei n. 13.129, de 26-52015. São Paulo: Saraiva, 2016, p. 475-492.

NAVARRINI, Umberto. Trattato di Dirrito Fallimentare: v. 1. Bologna: Nicola Zanchelli, 1934.

NEGRÃO, Ricardo. Aspectos objetivos da lei de recuperação de empresas e de falências: Lei n. 11.101, de 9 de fevereiro de 2005. 2. ed. rev. e atual. São Paulo: Saraiva, 2008.

NEGRÃO, Ricardo. Curso de Direito Comercial e de Empresa: v. 3. 13. ed. São Paulo: Saraiva Educação, 2019.

NERY JUNIOR, Nelson. Código de Processo Civil comentado. 11. ed. São Paulo: Revista dos Tribunais, 2010.

NERY JUNIOR, Nelson. Princípios do processo na Constituição Federal: processo civil, penal e administrativo. 9. ed. rev., ampl. e atual. com as novas súmulas do STF (simples e vinculantes) e com análise sobre a relativização da coisa julgada. São Paulo: Revista dos Tribunais, 2009. 
NITROLA, Marina. Arbitrato e Fallimento. I Contratti, n. 8-9, 2012, p. 756-759.

NONATO, Orosimbo. Curso de obrigações: v. 1. Rio de Janeiro: Forense, 1959.

NUNES, Thiago Marinho. A prática das anti-suit injunctions no procedimento arbitral e seu recente desenvolvimento no Direito brasileiro. Revista Brasileira de Arbitragem, v. 2, n. 5, p. 15-51, 2005.

OLIVEIRA, J. Lamartine Corrêa de. A dupla crise da pessoa jurídica. São Paulo: Saraiva, 1979.

OLIVERA, José Lamartine Corrêa de. A dupla crise da pessoa jurídica. São Paulo: Saraiva, 1979.

PACCHI, Stefania. Degli Effetti Del Fallimento. In: NIGRO, Alessandro; SANDULLI, Michele; SANTORO, Vittorio. La Legge Fallimentare Dopo La Riforma: t. 1: artt. 1-83 bis. Torino: G. Giappichelli, 2010, p. 571-586.

PACHECO, José da Silva. Processo de falência e concordata: comentários à lei de falência: doutrina, prática e jurisprudência. Rio de Janeiro: Forense, 2004

PAJARDI, Pietro; PALUCHOWSKI, Alida. Manuale di Diritto Fallimentare. 7. ed. Giuffrè, 2008.

PARENTE, Eduardo de Albuquerque. Processo arbitral e sistema. São Paulo: Atlas, 2012.

PARISI, Antonio. Articolo 42: beni del fallito. In: CAVALLINNI, Cesare. Commentario alla legge fallimentare: artt. 1-63. Egea, 2010, p. 881-894.

PARK, William W. Non-Signatories and International Contracts: An Arbitrator's Dilemma. In: PERMANENT COURT OF ARBITRATON. Multiple Party Actions in International Arbitration. Oxford: Oxford University, 2009.

PAUlA, Alexandre de. Código de Processo Civil anotado: v. 1. São Paulo: Revista dos tribunais, 1977.

PENALVA SANTOS, J. A. Obrigações e contratos na falência. Rio de janeiro: Renovar, 1997.

PENTEADO, Mauro Rodrigues. Disposições comuns à recuperação judicial e à falência. In: SOUZA JUNIOR, Francisco Satiro de (coord.); PITOMBO, Antônio Sérgio A. de Moraes (coord.). Comentários à Lei de recuperação de empresas e falência: Lei 11.101/2005: artigo por artigo. São Paulo: Revista dos Tribunais, 2007a, p. 131-143. 
PENTEADO, Mauro Rodrigues. Disposições preliminares. In: SOUZA JUNIOR, Francisco Satiro de (coord.); PITOMBO, Antônio Sérgio A. de Moraes (coord.). Comentários à Lei de recuperação de empresas e falência: Lei 11.101/2005: artigo por artigo. São Paulo: Revista dos Tribunais, 2007b, p. 57-129.

PEREIRA, Caio Mario da Silva. Instituições de Direito Civil. 18. ed. Rio de Janeiro: Forense, 1999.

PEREIRA, Caio Mario da Silva. Instituições de Direito Civil: v. 1. 20. ed. Rio de Janeiro: Forense, 2004.

PEREIRA, Caio Mario da Silva. Instituições de Direito Civil: v. 2. Rio de Janeiro: Forense, 2003.

PEREIRA, Caio Mario da Silva. Instituições de Direito Civil: v. 3. Rio de Janeiro: Forense, 2003.

PEREIRA, Thomaz Henrique Junqueira de Andrade. Princípios do direito falimentar e recuperacional brasileiro. Dissertação (Mestrado). Pontifícia Universidade Católica de São Paulo. São Paulo, 2009.

PINTO, José Emílio Nunes. A cláusula compromissória à luz do Código Civil. Migalhas, 28 set. 2004. Disponível em: https://www.migalhas.com.br/dePeso/16,MI7218,71043A+clausula+compromissoria+a+luz+do+Codigo+Civil. Acesso em: 14 nov. 2019.

PINTO, José Emílio Nunes. A confidencialidade na arbitragem. Revista de Arbitragem e Mediação, v. 2, n. 6, p. 25-36, jul./set. 2005.

PINTO, José Emílio Nunes. Confidencialidade em Arbitragem. Centro de Arbitragem e Mediação da Câmara de Comércio Brasil-Canadá - CCBC. 2005. Disponível em: http://www.ccbc.org.br/download/artarbit11.pdf. Acesso em: 23 jul. 2013.

PITOMBO, Eleonora C.. Os efeitos da convenção de arbitragem: adoção do princípio kompetenz-kompetenz no brasil. In: LEMES, Selma M. Ferreira; CARMONA, Carlos Alberto; e MARTINS, Pedro A. Batista (coord.). Arbitragem: estudos em homenagem ao Prof. Guido Fernando Silva Soares. São Paulo: Atlas, 2007, p. 326-338.

PONTES DE MIRANDA, Francisco Cavalcanti. Comentários à Constituição de 1946, v. 3. Rio de Janeiro: Imprensa Nacional, 1947.

PONTES DE MIRANDA, Francisco Cavalcanti. Tratado das ações. t. 1. Campinas, SP: Bookseller, 1998.

PONTES DE MIRANDA, Francisco Cavalcanti. Tratado de Direito Privado: t. 3. São Paulo: Revista dos Tribunais, 2012. 
PONTES DE MIRANDA, Francisco Cavalcanti. Tratado de Direito Privado: t. 4. São Paulo: Revista dos Tribunais, 2013.

PONTES DE MIRANDA, Francisco Cavalcanti. Tratado de Direito Privado: t. 5. São Paulo: Revista dos Tribunais, 2013.

PONTES DE MIRANDA, Francisco Cavalcanti. Tratado de Direito Privado: t. 23. São Paulo: Revista dos Tribunais, 2012.

PONTES DE MIRANDA, Francisco Cavalcanti. Tratado de Direito Privado: t. 44. São Paulo: Revista dos Tribunais, 2013.

PONTES DE MIRANDA, Francisco Cavalcanti. Tratado de Direito Privado: t. 26. São Paulo: Revista dos Tribunais, 2012.

PONTES DE MIRANDA, Francisco Cavalcanti. Tratado de Direito Privado: t. 27. São Paulo: Revista dos Tribunais, 2012.

PONTES DE MIRANDA, Francisco Cavalcanti. Tratado de Direito Privado: t. 28. São Paulo: Revista dos Tribunais, 2012.

PONTES DE MIRANDA, Francisco Cavalcanti. Tratado de Direito Privado: t. 38. São Paulo: Revista dos Tribunais, 2012.

PROVINCIALI, Renzo. Trattato di Diritto Fallimentare: t. 2. Milano: Giuffrrè, 1974.

PUCCI, Adriana Noemi. O princípio competência-competência. Revista do Advogado, v. 33, n. 119, p. 13-22, abr. 2013

PUGLIESI, Adriana Valéria. Direito Falimentar e preservação da empresa. São Paulo: Quartier Latin, 2013.

RAMELLA, Agostino. Trattato del fallimento: v. 1. Milano: Societa Editrice Libraria, 1903.

RAMELLA, Agostino. Trattato del fallimento: v. 2. Milano: Societa Editrice Libraria, 1903.

RANZOLIN, Ricardo. Controle judicial da arbitragem. Rio de Janeiro: GZ, 2011.

RÁO, Vicente. Ato jurídico: noção, pressupostos, elementos essenciais e acidentais: o problema do conflito entre os elementos volitivos e a declaração. 3. ed. anot. e atual. São Paulo: Revista dos Tribunais, 1994. 
RECCHIONI, Stefano. Articolo 24: Competenza del tribunale fallimentare. In: CAVALLINNI, Cesare. Commentario alla legge fallimentare, Artt. 1-63. Egea, 2010, p. 469-553.

RECENA COSTA, Guilherme. Partes e terceiros na arbitragem. Tese (Doutorado) Faculdade de Direito, Universidade de São Paulo. São Paulo, 2015.

RECHSTEINER, Beat Walter. Efeitos jurídicos da decretação da falência e da concessão da recuperação judicial em relação à arbitragem no direito brasileiro. In: LEMES, Selma M. Ferreira; CARMONA, Carlos Alberto; MARTINS, Pedro A. Batista (coord.). Arbitragem: estudos em homenagem ao Prof. Guido Fernando Silva Soares. São Paulo: Atlas, 2007, p. 351-371.

REDFERN, Alan; HUNTER, Martin. Law and Pratice of International Arbitration. 2. ed. London, UK: Sweet \& Maxwell, 1991.

REQUIÃO, Rubens. Curso de Direito Falimentar: v. 1. São Paulo: Saraiva, 1978.

REQUIÃO, Rubens. Curso de Direito Falimentar: v. 2. São Paulo: Saraiva, 1978.

RESNICK, Alan. The Enforceability of Arbitration Clauses in Bankruptcy. American Bankruptcy Institute Law Review, v. 15, p. 183-221, 2007.

ROMERO, Eduardo Silva (Dir. Académico); ESPINOSA, Fabricio Mantilla (Coord. Académico). El contrato de arbitraje. Bogotá: Legis, 2005.

ROPPO, Enzo. O contrato. Coimbra: Livraria Almedina, 1988.

ROSELL, José; PRAGER, Harvey. International Arbitration and Bankruptcy: United States, France and the ICC. Journal of International Arbitration. Kluwer Law International, v. 18, n. 4, p. 417-434, 2001

SACRAMONE, Marcelo. Comentários à lei de recuperação de empresas e falência. São Paulo: Saraiva Educação, 2018.

SADDI, Jairo. Arbitragem em matéria falimentar e liquidação extrajudicial. In: CASTRO, Rodrigo Rocha Monteiro de; WARDE JUNIOR, Walfrido Jorge; GUERREIRO, Carolina Dias Tavares (coord.). Direito Empresarial e outros estudos em homenagem ao Professor José Alexandre Tavares Guerreiro. São Paulo: Quartier Latin, 2013, p. 641662.

SADOWSKI, Wojciech. The European and Middle Eastern Arbitration Review 2011. 18 out. 2010. Acesso em: https://globalarbitrationreview.com/insight/the-european-middleeastern-arbitration-review-2011/1036638/poland. Acesso em: 22 nov. 2019. 
SALAMA, Bruno Meyerhof; PUGLIESE, Antonio Celso Fonseca. A economia da arbitragem: escolha racional e geração de valor. Revista Direito GV, n. 7, p. 15-28. , jan./jun. 2008

SALOMÃO FILHO, Calixto. Breves notas sobre transparência e publicidade na arbitragem societária. Revista de Arbitragem e Mediação, v. 52, p. 63-69, jan./mar. 2007.

SAMPAIO DE LACERDA, J. C. Manual de Direito Falimentar. 14. ed. Rio de Janeiro: Freitas Bastos, 1999,

SAMPAIO DE LACERDA, J. C. Manual de Direito Falimentar. 14. ed. rev. e atual. Rio de Janeiro: Freitas Bastos, 1999.

SANTOS, Elenise Peruzzo dos. Os princípios clássicos e atuais da lei de falências e recuperação de empresas. In: BATTELO, Sílvio Javier. Principais controvérsias na nova lei de falências. Porto Alegre: Fabris, 2008, p. 13-36.

SATTA, Salvatore. Dirrito Fallimentare. Padova: CEDAM, 1974.

SATTA, Salvatore. Istituzioni di Diritto Fallimentare. 4. ed. Roma: Foro Italiano, 1953.

SCALZILLI, João Pedro; SPINELLI, Luis Felipe; TELLECHEA, Rodrigo. Recuperação de empresas e falência: teoria e prática na Lei 11.101/2005. 3. ed. rev., atual. e ampl. São Paulo: Almedina, 2018.

SIDOU, J. M Othon. A revisão judicial dos contratos e outras figuras jurídicas: a cláusula repus sic stantibus; dos efeitos da fiança; empresa individual de responsabilidade limitada. Rio de Janeiro: Forense. 1934

SILVA, Eduardo Silva da. Arbitragem e Direito da Empresa: dogmática e implementação da cláusula compromissória. São Paulo: Revista dos Tribunais, 2003.

SILVEIRA, Gustavo Scheffer da. O papel do juiz no fortalecimento da arbitragem: efeito negativo da competênciacompetência v. anti-suit injunctions. Revista Brasileira de Arbitragem. Kluwer Law International, v. 15, n. 60, p. 44-58, 2018.

SIMIONATO, Frederico A. Monte. Tratado de Direito Falimentar. Rio de Janeiro: Forense, 2008.

SIOUFI FILHO, Alfred Habib. Denegação de Justiça. Revista Brasileira de Arbitragem, edição especial: A proteção ao investimento estrangeiro, p. 161-179, 2011.

SOUZA JUNIOR, Francisco Satiro de; PITOMBO, Antônio Sérgio A. de Moraes (coord.). Comentários à Lei de recuperação de empresas e falência: Lei 11.101/2005: artigo por artigo. São Paulo: Revista dos Tribunais, 2007. 
STEIN, Raquel. Arbitrabilidade no Direito Societário. Rio de Janeiro: Renovar, 2014.

STRECK, Lênio Luiz. O novo Código de Processo Civil (CPC) e as inovações hermenêuticas: o fim do livre convencimento e a adoção do integracionismo dworkiniano. Revista de Informação Legislativa, v. 52, n. 206, p. 33-51, abr./jun. 2015.

SZTAJN, Rachel. Comentários ao art. 150. In: TOLEDO, Paulo Fernando Campos Salles de; ABRÃO, Carlos Henrique (coord.). Comentários à Lei de recuperação de empresas e falência. São Paulo: Saraiva, 2009, p. 465-466.

SZTAJN, Rachel. Comentários ao art. 50. In: SOUZA JUNIOR, Francisco Satiro de (coord.); PITOMBO, Antônio Sérgio A. de Moraes (coord.). Comentários à Lei de recuperação de empresas e falência: Lei 11.101/2005: artigo por artigo. São Paulo: Revista dos Tribunais, 2007, p. 231-247.

SZTAJN, Rachel. Contrato de Sociedade e formas societárias. São Paulo: Saraiva, 1989.

TARREGA, Maria Cristina Vidotte Blanco. Comentários aos artigos 102 ao 104. In: DE LUCCA, Newton; SIMÃO FILHO, Adalberto (coord.). Comentários à Nova Lei de Recuperação de Empresas e de Falências. São Paulo: Quartier Latin, 2005.

TAVARES GUERREIRO, José Alexandre. Da verificação de créditos. In: SOUZA JUNIOR, Francisco Satiro; PITOMBO, Antonio Sérgio A. e Moraes (coord.). Comentários à lei de recuperação de empresas e falência: Lei 11.101/2005. São Paulo: Revista dos Tribunais, 2007, p. 144-162.

TAWIL, Guido Santiago. National Report for Argentina (2019). In: BOSMAN, Lise. (ed.). ICCA International Handbook on Commercial Arbitration. ICCA \& Kluwer Law International 2019, Supplement n. 107, p. 1-54, 2019.

TELLECHEA, Rodrigo. Sociedades anônimas fechadas: direitos individuais dos acionistas e cláusula compromissória estatutária superveniente. Tese (Doutorado) Faculdade de Direito, Universidade de São Paulo. São Paulo, 2015.

TEPEDINO, Ricardo. Comentários aos arts. 105-137. In: TOLEDO, Paulo F. C. Salles; ABRÃO, Carlos Henrique (coord.). Comentários à lei de recuperação de empresas e falência. 3. ed. rev. e atual. São Paulo: Saraiva, 2009, p. 236-429.

THEODORO JÚNIOR, Humberto. Curso de Direito Processual Civil: v. 1. 26. ed. Rio de Janeiro: Forense, 2001.

THEODORO JÚNIOR, Humberto. Curso de Direito Processual Civil: v. 3. 26. ed. Rio de Janeiro: Forense, 2001.

THEODORO JÚNIOR, Humberto. Processo de execução. 11. ed. São Paulo: Livraria e Universitária de Direito, 1986. 
TOLEDO, Paulo F. C. Salles de. Arbitragem e insolvência. Revista de Arbitragem e Mediação, v. 6, n. 20, jan./mar. 2009a, p. 25-52.

TOLEDO, Paulo F. C. Salles. Comentários aos arts. 1-34. In: TOLEDO, Paulo F. C. Salles; ABRÃO, Carlos Henrique (coord.). Comentários à lei de recuperação de empresas e falência. 3. ed. rev. e atual. São Paulo: Saraiva, 2009b, p. 2-93.

TOLEDO, Paulo Fernando Campos Salles de; PUGLIESI, Adriana V. Capítulo XI - A falência: noções gerais. In: CARVALHOSA, Modesto (coord.). Tratado de Direito Empresarial: v. 5: recuperação judicial e falência. São Paulo: Revista dos Tribunais, 2016.

TOMAZZETTE, Marlon. Curso de Direito Empresarial: v. 3: falência e recuperação de empresas. São Paulo: Saraiva Educação, 2019.

TONIN, Mauricio Morais. Direito patrimonial disponível da Administração Pública: tentativa de definição. In: LEE, João Bosco; MANGE, Flavia (ed.). Revista Brasileira de Arbitragem, v. 15, n. 59, p. 61-79, 2018.

TORNAGHI, Hélio. Comentários ao código de processo civil: v. 1. São Paulo: Revista dos Tribunais, 1974.

TRABUCCHI, Alberto. Instituciones de Derecho Civil: v. 1. Madrid: Editorial Revista Derecho Privado, 1967.

TUCCI, Rogério Lauria; CRUZ e TUCCI, Jose Rogério. Devido processo legal e tutela jurisdicional. São Paulo: Revista dos Tribunais, 1993.

UBALDINO MIRANDA, Custódio da Piedade. Interpretação e integração dos negócios jurídicos. São Paulo: Revista dos Tribunais, 1989.

VALENÇA FILHO, Clávio de Melo. A arbitragem em juízo. Tese (Doutorado) Faculdade de Direito, Universidade de São Paulo. São Paulo, 2015.

VASCONCELOS, Ronaldo; CARNAÚBA, César Augusto Martins et al. Financiamento de terceiros e arbitragem no processo concursal. Revista Brasileira de Arbitragem, v. 16, n. 61, p. 36-62, 2019a.

VASCONCELOS, Ronaldo; CARNAÚBA, César Augusto Martins. Arbitragem, insolvência e o dilema da publicidade. Revista de Processo, v. 292, p. 399-432, 2019b.

VELLA, Paola. Art. 42 1.f. In: FERRO, Massimo. La legge Fallimentare commentario teorico-pratico. Padova: CEDAM, 2014, p. 582-600.

VERÇOSA, Haroldo Malheiros Duclerc (org.). Aspectos da arbitragem institucional: 12 anos da Lei 9.307/1996. São Paulo: Malheiros, 2008. 
VERÇOSA, Haroldo Malheiros Duclerc. A cláusula compromissória e o art. 117, caput, da lei de recuperação de empresas e falência. Migalhas, 9 jan. 2020. Disponível em: https://www.migalhas.com.br/dePeso/16,MI318070,61044-

A+clausula+compromissoria+e+o+art+117+caput+da+lei+de+recuperacao+de. Acesso em: 10 jan. 2020.

VERÇOSA, Haroldo Malheiros Duclerc. Direito comercial: teoria geral do contrato. 2. ed. rev., atual. e ampl. São Paulo: Revista dos Tribunais, 2014. [Coleção "Direito Comercial", v. 4].

VERÇOSA, Haroldo Malheiros Duclerc. Honorários contratuais e de sucumbência na arbitragem. Migalhas, 18 nov. 2019. Disponível em: https://www.migalhas.com.br/dePeso/16,MI315209,31047-

Honorarios+contratuais+e+de+sucumbencia+na+arbitragem. Acesso em: 05 jan. 2020.

VICENTE, Dário Moura. National Report for Portugal (2018 through 2019). ICCA International Handbook on Commercial Arbitration. Kluwer Law International, Supplement n. 104, p. 1-40, fev. 2019.

VIEIRA, Maíra de Melo. A obrigatoriedade da cláusula compromissória em caso de litígios envolvendo empresas sujeitas a processos de falência ou recuperação. Revista de Arbitragem e Mediação. São Paulo: RT, v. 7, n. 28, jan./mar. 2011.

VISSCHER, Charles de. Le déni de justice em Droit International. Recueil des Cours de La Haye, t. 52, 1935.

VORBURGER, Simon. International Arbitration and Cross-Border Insolvency: Comparative Perspectives. The Hague: Kluwer International, 2014.

VOSER, Nathalie; GEORGE, Anya. Insolvency and Arbitration: Swiss Supreme Court revisits its Vivendi vs. Elektrim decision. Kluwer Arbitration Blog, 05 dez. 2012. Disponível em: http://arbitrationblog.kluwerarbitration.com/2012/12/05/insolvency-andarbitration-swiss-supreme-court-revisits-its-vivendi-vs-elektrim-decision. Acesso em: 22 nov. 2009.

WAGNER, Gerhard. Impecunious Parties and Arbitration Agreements. German Arbitration Journal. Kluwer Law International, v. 1, n. 5, p. 206-218, 2003.

WAGNER, Philipp. Insolvency and Arbitration: A Pleading for International Insolvency Law. 5 Disp. Rsol. Int'l 189, 2011. Disponível em: https://heinonline.org/HOL/LandingPage?handle=hein.journals/disreint5\&div=20\&id=\&pa ge=. Acesso em: 5 jan. 2020 .

WATANABE, Kazuo. Acesso à justiça e sociedade moderna. In: GRINOVER, Ada Pellegrini; DINAMARCO, Cândido Rangel; WATANABE, Kazuo (coord.). Participação e processo. São Paulo: Revista dos Tribunais, 1988. 
WLADECK, Felipe Scripes. Impugnação da sentença arbitral. Salvador: Juspodivm, 2014.

ZANINI, Carlos Klein. Comentários ao art. 76. In: SOUZA JUNIOR, Francisco Satiro de (coord.); PITOMBO, Antônio Sérgio A. de Moraes (coord.). Comentários à Lei de recuperação de empresas e falência: Lei 11.101/2005: artigo por artigo. São Paulo: Revista dos Tribunais, 2007, p. 340-344.

ZANINI, Carlos Klein. Comentários ao art. 77. In: SOUZA JUNIOR, Francisco Satiro de (coord.); PITOMBO, Antônio Sérgio A. de Moraes (coord.). Comentários à Lei de recuperação de empresas e falência: Lei 11.101/2005: artigo por artigo. São Paulo: Revista dos Tribunais, 2007, p. 344-346.

ŽIVKOVIĆ, Patricia. Impecunious Parties in Arbitration: An Overview of European National Courts" Practice. Croatian Arbitration Yearbook, v. 23, 13 dez. 2016.

ZUCCONI GALLI FONSECA, Elena. Ancora su arbitrato rituale e fallimento. Rivista Dell'Arbitrato, n.1, p. 1-27, 2014. 